\title{
Slaughter-House Five: Views of the Case
}

\author{
DAvid S. BogEN*
}

\begin{abstract}
Because I believe that the demise of the Privileges or Immunities Clause has contributed in no small part to the current disarray of our Fourteenth Amendment jurisprudence, I would be open to reevaluating its meaning in an appropriate case. Before invoking the Clause, however, we should endeavor to understand what the framers of the Fourteenth Amendment thought that it meant. We should also consider whether the Clause should displace, rather than augment, portions of our equal protection and substantive due process jurisprudence.
\end{abstract}

-Saenz v. Roe (Thomas, J., dissenting, joined byRehnquist, C.J.)

"No State shall make or enforce any law which shall abridge the privileges or immunities of citizens of the United States." The SlaughterHouse Cases said these words did not refer to the fundamental rights of citizens, but to rights derived from "the Federal government, its national character, its Constitution or its laws." 3 Since that decision, the Supreme Court has made it clear that the privileges or immunities clause of the Fourteenth Amendment is not itself the source of any rights, and has turned to the due process and equal protection clauses of the Fourteenth Amendment for protection of "fundamental rights," including incorporation of some of the Bill of Rights. ${ }^{4}$ This is the jurisprudence that Justice

* Professor of Law and T. Carroll Brown Scholar, University of Maryland School of Law. B.A. 1962, LL.B. I 965 Harvard University; LL.M. 1967 New York University. I would like to thank Professor Alan Chen of the University of Denver and Gordon Young here at Maryland as well as faculty at the University of Denver and the University of Maryland who participated in workshops discussing the paper. I would also like to thank Jennifer Cupani and Rob Burriesci, Maryland School of Law class of 2004 , for their research assistance on this article.

I. 526 U.S. $489,527-28$ (1999).

2. U.S. Const. amend. XIV, § I.

3. 83 U.S. ( 6 Wall.) 36,79 ( 1872 ).

4 See generally Twining v. New Jersey, 2 I I U.S. 78, 97, 99 (1908) (holding source of privileges and immunities is found in nature and essential character of national government and rights specifically granted by Constitution; Privileges and Immunities Clause does not incorporate Bill of Rights, but bill of rights may apply to states through due process clause if fundamental principle of liberty and justice); Gitlow v. New York, 268 U.S. 652, 666 (1925) (holding Freedom of Speech guaranteed by First Amendment applies to states as requirement of due process under Fourteenth Amendment); Strauder v. West Virginia, Ioo U.S. 303, 3 Io ( 1880 ) (holding racial discrinination in jury pool violates 
Clarence Thomas and Chief Justice William Rehnquist questioned in dissent in Saenz. ${ }^{5}$ These justices may regret the reevaluation they call for, because it could overturn the "new federalism" they hold so dear. ${ }^{6}$ However, this Article contends that the current Fourteenth Amendment jurisprudence including the "demise of the Privileges or Immunities Clause" should be reaffirmed.

The Slaughter-House Cases held that, in the absence of federal legislation, a state did not violate the Thirteenth or Fourteenth Amendment when it created a monopoly as part of the regulation of an industry that posed public health dangers. ${ }^{7}$ The result was far less controversial than the Court's rationale, which distinguished fundamental rights from privileges or immunities. That distinction set the course for analysis of the privileges or immunities clause and made the Slaughter-House Cases pivotal to the understanding of current doctrine.

This Article discusses five different views of the Slaughter-House Cases. First, this Article examines three views on whether the majority opinion intended to make the Bill of Rights applicable against the states: (I) that it was intentionally ambiguous, (2) that it precluded incorporation, or (3) that it supported incorporation of the Bill of Rights against the states. Second, the Article takes up Justice Thomas's challenge to reevaluate the interpretation of the privileges or immunities clause and considers whether (4) the Slaughter-House Cases should be overruled or (5) followed.

The conventional view of Justice Samuel F. Miller's majority opinion in the Slaughter-House Cases rejects incorporation of the Bill of Rights against the states through the privileges and immunities clause, but a revisionist theory that the opinion supports incorporation ${ }^{8}$ has been gaining

equal protection clause); Lawrence v. Texas, I23 S.Ct. 2472, 2484 (2003) (holding criminalization of homosexual conduct violates due process because adults have fundamental right to autonomy in intimate choices).

5. Saenz, 526 U.S. at 521 .

6. James W. Fox, Jr., Re-readings and Misreadings: Slaughter-House, Privileges or Immunities, and Section Five Enforcement Powers, 91 Ky. L.J. 67, 67 (2002) (arguing for congressional power to interpret the clause under Section 5) [hereinafter Fox, Re-readings and Misreadings]; William J. Rich, Privileges or Immunities: The Missing Link in Establishing Congressional Power to Abrogate State Eleventh Amendment Immunity, 28 HASTINGs Const. L.Q. 235, 238 (200I) [hereinafter Rich, Privileges or Immunities] (arguing that Privileges and Immunities Clause authorizes Congress to abrogate states' sovereign immunity when acting to enforce individual rights that Congress has been authorized to protect); William J. Rich, Taking "Privileges or Immunities" Seriously: A Call to Expand the Constitutional Canon, 87 MinN. L. Rev. I53, 230 (2002) [hereinafter Rich, Taking "Privileges or Immunities" Seriously] (arguing private causes of action against states are exercises of Section 5 enforcement power).

7. 83 U. S. (Wall.) at $62-65$.

8. Robert C. Palmer, The Parameters of Constitutional Reconstruction: Slaughter-House, Cruikshank, and the Fourteenth Amendment, 1984 U. ILL. L. Rev. 739, 769 (1984); Kevin Christopher Newsom, Setting Incorporationism Straight: A Reinterpretation of the Slaughter-House Cases, I09 
ground. ${ }^{9}$ Revisionist success could have dramatic effect. First, by suggesting that the Slaughter-House Cases have been misinterpreted, the revisionist view opens the door to switching incorporation doctrine from the due process clause to the privileges or immunities clause. ${ }^{10}$ Second, this view of the Slaughter-House Cases supports total incorporation as articulated by Justice Black, rather than the current process of selective incorporation. ${ }^{\text {II }}$ This would make grand jury indictment, the civil jury, and the right to bear arms applicable to state government despite the prior Supreme Court decisions to the contrary. ${ }^{12}$ Third, by basing incorporation on the Slaughter-House Cases, which repudiated a fundamental rights approach to the privileges or immunities clause, these articles weaken the unenumerated rights premise that lies at the heart of cases like Roe $v$. Wade. $^{13}$

YALE L.J. 643, 647-48 (2000); Bryan H. Wildenthal, The Lost Compromise: Reassessing the Early Understanding in Court and Congress on Incorporation of the Bill of Rights in the Fourteenth Amendment, 6r Oнiо Sr. L.J. 105I, 1054-55 (2000).

9. Kevin Newsom's lead article in the Yale Law Journal has attracted significant support. Newsom, supra note 8; see Rich, Taking "Privileges and Immunities" Seriously, supra note 6, at I80. Professor Tribe was also apparently persuaded by Newsom's views initially. Lawrence H. Tribe, Comment, Saenz Sans Prophecy: Does the Privileges or Immunities Revival Portend the Future-or Reveal the Structure of the Present?, II3 HaRv. L. Rev. I Io, I84 n.33I (1999) [hereinafter Tribe, Saenz Sans Prophecy]. He has subsequently appeared more ambivalent. I Lawrence H. Tribe, American Constrtutional LaW I303 n.3 (3d ed. 2000) [hereinafter Tribe, American Constrtutional Law].

Io. The premise of Newsom's work is that if Slaughter-House supported incorporation rather than negating it, the Court will find it easier to accept the privileges and immunities clause as the appropriate vehicle for applying the individual rights protections of the Constitution against the states. Newsom, supra note 8, at 733-44. But the most Newsom could denonstrate would be that dicta in an early case was misunderstood. It does not reverse the century of precedent that has relied on the due process clause to restrict the states and held that privileges and imnunities do not support incorporation. The interesting issue this raises on the role of precedent will not be addressed here.

II. Justice Hugo Black argued that the Bill of Rights was incorporated against the states because the Rights were specifically mentioned in the Constitution. Adamson v. California, 332 U.S. 46, 70 (1947) (Black, J., dissenting). The novelty of his theory was that he denied the existence of substantive due process or any unenumerated rights. His theory would expand the rights of the citizen by making the Bill of Rights applicable against the state, but cabin the Court's discretion by limiting the application to specifically enumerated rights. Although Black claimed support for his theory in history and in the dissenting opinions of a variety of individual judges, his sources based incorporation on the theory that the Fourteenth Amendment secured fundamental rights and the stated rights in the Constitution were examples of fundamental rights and not the only rights protected. Justice Black cited no source that espoused incorporation with his limitations on it. He seemed to accept the conventional wisdom of his day that the Slaughter-House Cases had rejected incorporation. Id. at 75-78 (Black, J., dissenting).

I2. Walker v. Sauvinet, 92 U.S. 90, 92 (I876) (civil jury); Maxwell v. Dow, I76 U.S. 58I, 595 (1900) (grand jury indictment); Presser v. Illinois, I I6 U.S. 252, 267-68 (I886) (right to bear arms).

13. 4 IO U.S. I13, 152 (1973). The move to substantive due process was facilitated by the use of due process to incorporate the substantive provisions of the Bill of Rights. If substantive guarantees such as freedom of speech apply to the states as privileges of United States citizenship rather than as liberty interests, the due process clause would be more likely to be interpreted as purely procedural. 
The dramatic consequences of reinterpreting the Slaughter-House Cases, especially when several members of the Supreme Court have signaled their willingness to reconsider the current interpretation of the privileges and immunities clause, prompted this Article. ${ }^{14}$ After examining the Slaughter-House Cases and the different arguments about its meaning, it concludes that the weight of the evidence supports the conventional wisdom that Justice Miller's majority opinion intended to strip the privileges or immunities clause of any independent significance and rejected its use to incorporate the Bill of Rights. ${ }^{15}$ Slaughter-House means just what we thought it meant. Incorporation of the Bill of Rights through the privileges and immunities clause would require the Court to reverse that decision as well as every subsequent decision made on the issue.

The next logical question is whether the Court should overturn the Slaughter-House Cases ${ }^{16}$ as a judicial mistake and center interpretation of the Fourteenth Amendment in the privileges and immunities clause. A wide range of critics, from Justice Thomas to Professor Lawrence Tribe, have urged the change. ${ }^{17}$ They argue that the decision was wrong historically and that its mistaken approach has created problems for constitutional doctrine that can only be surmounted by the revival of the privileges and immunities clause. ${ }^{18}$ The critics agree on overruling the decision, but they have many different opinions about what that should lead to. One view emphasizes congressional power to enforce the privileges or immunities of citizens of the United States under Section 5 of the Fourteenth Amendment, and argues for a shift to Congress of much of the responsibility for interpreting the substance of those terms. ${ }^{19}$ Such deference to congressional interpretation could reverse the Court's new federalism decisions. ${ }^{20}$

This Article takes another view and concludes that the majority acted correctly. The common criticism of the Court for nullifying the

This, of course, was the position of Justice Black, although he was willing to use whatever clause the rest of the Court would vote for. See Adamson, 332 U.S. at 68-92 (Black, J., dissenting).

I4 See infra Parts 11 and 111; supra note 8.

15. See infra Parts IV and V.

16. Id.

i7. Tribe, American Constitutional Law, supra note 9, at 13i7-23; Saenz v. Roe, 526 U.S. 489, 527-28 (1999) (Thomas, J., dissenting, joined by Rehnquist, C.J.).

I8. See Tribe, American Constitutional Law, supra note 9 at 13i7-23.

19. See Fox, supra note 6, at 68-70.

20. Deference to congressional determinations that the privileges or immunities of citizens of the United States include freedom from threats of guns, sexual violence, and discrimination based on age or disability would overturn United States v. Lopez, 5 I4 U.S. 549 (1995), United States v. Morrison, 529 U.S. 598 (2000) and perhaps Kimel v. Florida Bd. of Regents, 528 U.S. 62 (2000) and Bd. of Trs. of Univ. of Ala. v. Garrett, 53I U.S. 356 (200I). 
privileges and immunities clause is misplaced. ${ }^{21}$ Justice Miller accurately foresaw the potential of the clause to undermine federalism. Although the framers of the Fourteenth Amendment invested their hopes in the privileges and immunities clause, the combination of a broad interpretation of the equal protection clause and the current interpretation of the due process clause to mcorporate many of the Bill of Rights and some unenumerated rights more accurately reflects their intent than could be achieved under the privileges or immunities clause. Further, this result supports a balanced federalism that remains the best hope for resolving a variety of problems in the nation and the world.

\section{Slaughter-House One: Slaughter-House Cases Dicta Was Deliberately Ambiguous}

Although the Slaughter-House Cases repudiated a fundamental rights construction of the privileges or immunities clause, the Court's language was less clear on whether the clause incorporated the Bill of Rights agamst the state. The fundamental rights discussion provided the rationale for the holding, but an ambiguous mention of specific constitutional provisions was dicta. Professor Fox has suggested that the ambiguity was deliberate and the majority intended to postpone making any decision on the point. ${ }^{22}$ In his view, the case is not a precedent with respect to the use of the privileges or immunities clause to apply the first eight Amendments against the states.

\section{A. The Rationale's Rejection of Fundamental Rights}

The Fourteenth Amendment to the Constitution was adopted to deal with the aftermath of slavery and the racial discrimination that prevailed after the Civil War. The first sentence asserts that "All persons born or naturalized in the United States, and subject to the jurisdiction thereof, are citizens of the United States and of the State wherein they reside." ${ }^{23}$ This repudiated Taney's Dred Scott opinion on AfricanAunerican citizenship. ${ }^{24}$ The framers wished to secure for all citizens the privileges and immunities of citizens to which Article IV of the Constitution referred when it said that "The Citizens of each State shall be entitled to all Privileges and Immunities of Citizens in the several States."25 Supporters of the new Amendment intended to make a constitutional principle of the Civil Rights Act of 1866 , which stated that citizens

21. See Fox, supra note 6 , at $70-72$.

22. Id. at 79 .

23. U.S. Const. amend. XIV, \& I.

24. See Dred Scott v. Sandford, 60 U.S. (19 How.) 393, 407 (1856) (holding that African Americans, whether free or slave, are not citizens).

25. U.S. Const. art. IV, $\$ 2$. 
shall have the same right ... to make and enforce contracts, to sue, be parties' and give evidence, to inherit, purchase, lease, sell, hold, and convey real and personal property, and to [have] full and equal benefit of all laws and proceedings for the security of person and property, as is enjoyed by white citizens, and shall be subject to like punishment, pains, and penalties, and to none other .... ${ }^{26}$

Every speaker in Congress who touched on the issue during the discussion of the adoption of the privileges or immunities clause of the Fourteenth Amendment clause either stated that it was derived from the privileges and immunities clause of Article IV or that it made the Civil Rights Act into a constitutional command, or both. ${ }^{27}$ Thus, "privileges or immunities" referred to the fundamental rights that citizens ought to enjoy in any society, because congressmen understood that the term meant fundamental rights in Article IV and because the prohibition of racial discrimination in fundamental rights was the basic principle of the Civil Rights Act of 1866.

The privileges and immunities of citizens that Article IV protected against discrimination based on state of citizenship were never completely defined, but congressmen and judges generally described them as fundamental rights prior to the Fourteenth Amendment. ${ }^{28}$ They included rights to acquire and possess property. Northern republicans also claimed that southern states violated Article IV when they denied free African Americans and northern whites entrance into the state, rights of speech within the state, and the ability to sue for their rights in the state courts. ${ }^{29}$

26. Civil Rights Act, ch. 3 I, \& I, I4 Stat. 27 (I866).

27. See Cong. Globe, 39th Cong., Ist Sess. 2459 (1866) (Rep. Stevens); id. at 2462 (Rep. Garfield); id. at 2465 (Rep. Thayer); id. at 2467 (Rep. Boyer); id. at 2498 (Rep. Broomall); id. at 2502, 25I3 (Rep. Raymond); id. at 25II (Rep. Eliot); id. at 2539 (Rep. Farnsworth); id. at 2542-43 (Rep. Bingham); id. at 2765 (Sen. Howard); id. at 2896 (Sen. Doolittle); id. at 296I (Sen. Poland); id. at app. 219 (Sen. Howe); id. at 3035 (Sen. Henderson).

28. Senator Lyman Trumbull, proposing the Civil Rights Act, said the rights secured by Article IV were "such fundamental rights as belong to every free person," citing Bushrod Washington's decision in Corfield v. Coryell, 6 F. Cas. 546 (C.C.E.D. Pa. I823) (No. 3,230). Cong. Globe, 39th Cong., ist Sess. 474 ( 1866 ) (Sen. Trumbull). Representative Lawrence of Ohio said "the absolute right to live, the right of personal security, personal liberty, and the right to acquire and enjoy property. These are the rights of citizenship." Id. at 1833 (Rep. Lawrence). He then said "the privileges referred to in the Constitution are such as are fundamental civil rights." Id. at I836 (Rep. Lawrence).

29. Representative Kasson claimed that slavery should be abolished because it caused a violation of Article IV privileges and immunities by driving people from the state because of their opinions. "Did not Massachusetts send two distinguished gentlemen to try a cause affecting the right of South Carolina over frec colored citizens of Massachusetts in the courts of South Carolina, and were they not driven ignominiously from the city of Charleston, without access to the court?" Cong. GLoBE, 38th Cong., 2d Sess. 193 (I865) (Rep. Kasson); Representative Smith, citing Article IV, said "That principle was denied to the whole North by the South unless the man adhered to the sentiments of the South." Id. at 237 (Rep. Smith); and Representative Higby, referring to the initial proposal for Congressional power to enforce privileges and immunities, bemoaned the failure to effectuate Article IV that produced the need for the new amendment: "Had that provision been enforced, a citizen of New York 
Thus, fundamental rights included affirmative benefits from the state (e.g., suit in court, enforceable property and contract rights) and negative rights against state interference (e.g., interstate movement, free speech).

The Civil Rights Act of I866 was the epitome of fundamental rights. Its principle was that racial discrimination in contract, property, access to and testimony in courts, in laws for the security of person and property, or in punishments, deprived citizens of fundamental rights that were privileges or immunities of citizenship. Republican supporters argued that the law was a valid exercise of congressional power to enforce the Thirteenth Amendment, because the failure to treat the individual as a citizen was a badge or incident of slavery. ${ }^{30}$

Although congressmen voting on the Fourteenth Amendment believed that "privileges or immunities" referred to fundamental rights, ${ }^{31}$ the Slaughter-House Cases rejected a fundamental rights interpretation of the clause only five years after the Amendment's ratification. ${ }^{32}$ The Slaughter-House Cases arose from a monopoly to operate a slaughterhouse in New Orleans that the Louisiana legislature granted the Crescent City Livestock Company. ${ }^{33}$ The justification for regulating slaughterhouses may have been the stench and pollution produced by massive slaughtering, but those emissions were a pale reflection of the corruption of the political process that secured the monopoly. ${ }^{34}$ Nevertheless, bribery was not the basis for challenging the grant. ${ }^{35}$

In the Slaughter-House Cases, the plaintiff butchers claimed that the monopoly violated the Fourteenth Amendment primarily because it deprived them of the privilege and immunity of pursuing a trade on terms applicable to everyone. ${ }^{36}$ Counsel for the defendant slaughterhouse com-

would have been treated as a citizen in the State of South Carolina." Cong. GLOBE, 39th Cong., Ist Sess. 1054 (1866) (Rep. Higby).

3o. Senator Lyman Trumbull of lllinois, proposing the Civil Rights Act, pointed to privileges and immunities as fundamental rights in Article IV. Cong. Globe, 39th Cong., Ist Sess. 474 (I866) (Sen. Trumbull). Then he said that if citizens of other states are entitled to such rights when in a state, "how much more are the native-born citizens of the State itself entitled to these rights!" Id. at 475 (Sen. Trumbull). Representative Lawrence of Ohio argued that the Act was justified as a measure to enforce the privileges and immunities clause of Article IV. Id. at 1835-36 (Rep. Lawrence).

3I. See Cong. Globe, 39th Cong. Ist Sess. (I866), supra notes 28 and 30.

32. Slaughter-House Cases, 83 U.S. (I6 Wall.) 36,60 (1872).

33. Id. at $59-60$.

34. Id. at 59-61, 64-66.

35. Fletcher v. Peck, io U.S. (6 Cranch) 87 , I23 (1810), ended that route. It held that Georgia violated the contract clause when it attempted to reverse an agreement with the state that had allegedly been procured by bribery. $I d$.

36. Slaughter-House Cases, 83 U.S. (16 Wall.) at 50-54; Brief for Plaintiffs at 2-3, SlaughterHouse Cases, 83 U.S. 36 ( 1872 ) (Nos. $475-80$ ), in 6 Philip B. Kurland \& Gerhard Casper, ed., Landmark Briefs and arguments of the Supreme Court of the United States: Constitutional LAW 537-38 (1975) [hereinafter Brief for Plaintiffs]. 
pany accepted the proposition that the privileges and immunities specified in the Fourteenth Amendment were the fundamental rights of citizens, including the right to pursue a trade, but argued that the Amendment protected those rights only against discrimination based on race. ${ }^{37}$

Justice Samuel Miller wrote the majority opinion, in which he was joined by Justices Nathan Clifford, David Davis, William Strong, and Ward Hunt.$^{38} \mathrm{He}$ rejected the fundamental rights views of the privileges or immunities clause held by counsel on both sides of the case..$^{39}$ Mixing text and policy analysis, Miller concluded that the privileges and immunities of citizens of the United States were distinct from the fundamental rights of citizens. ${ }^{40}$ The Fourteenth Amendment's text makes citizenship in the United States depend on place of birth, and state citizenship depend on place of residence. ${ }^{41}$ Noting that citizenship in the United States and citizenship in a state are different matters that depend on different characteristics, Miller said:

It is a little remarkable, if this clause was intended as a protection to the citizen of a State against the legislative power of his own State, that the word citizen of the State should be left out when it is so carefully used, and used in contradistinction to citizens of the United States in the very sentence which precedes it. It is too clear for argument that the change in phraseology was adopted understandingly and with a purpose.

Justice Miller said that the privileges and immunities protected by Article IV were those of state citizens. ${ }^{43}$ Those rights embrace "nearly

37. Brief of Counsel of Defendant in Error at 4-9, Slaughter-House Cases, 83 U.S. 36 (1872) (Nos. 475-80), in 6 Philip B. Kurland \& Gerhard Casper, eds., Landmark Briefs and Arguments of the Supreme Court of the United States: Constrtutional Law 609-14 (1975) [hereinafter Brief of Counsel of Defendant in Error].

38. Miller began by showing that regulation of slaughterhouses was within the police power of the states, and noting that all state constitutional issues had been resolved by the state court. SlaughterHouse Cases, 83 U.S. ( 16 Wall.) at $6 \mathrm{I}-66$. He then discussed the adoption of the Civil War Amendments, observing that the monopoly was a servitude on property (prohibiting use as slaughter house) rather than of person, and therefore the Thirteenth Amendment did not apply. Id. at 66-74. He then moved to the privileges and immunities argument. Id. at $73-83$.

39. Bryan Wildenthal suggested that incorporationist arguments in the plaintiffs' brief indicate incorporation was on the mind of the justices and that Miller's opinion should be read to support that theory. Wildenthal, supra note 8, at I I I I. However, Miller rejected the fundamental rights interpretation of the amendment that the briefs on both sides supported. See generally Brief of Counsel of Defendant in Error, supra note 37 and Brief for Plaintiffs, supra note 36 . The losing brief's subtle reference to incorporation based on a fundamental rights theory should not affect the interpretation of an opinion that flatly rejects the main thesis proposed.

40. Slaughter-House Cases, 83 U.S. ( 16 Wall.) at $76-81$.

41. Id. at 80 .

42. Id. at 74 .

43. Id. at 76 . 
every civil right for the establishment and protection of which organized government is instituted. They are ... those rights which are fundamental[,]" and they encompass "the class of rights which the State governments were created to establish and secure." ${ }^{44}$ But those privileges were secured only against discrimination based on state of citizenship. If a state denied a fundamental right to its own citizens, it could deny it to others. ${ }^{45}$ Miller argued these privileges and immunities in Article IV were quite distinct from the privileges and immunities of citizens of the United States protected by the Fourteenth Amendment. ${ }^{46}$ The right to pursue a trade was a fundamental right of citizenship within Article IV's protection against discrimination based on state residence. ${ }^{47}$ It was not, however, a privilege or immunity of United States citizenship. ${ }^{48}$ An interpretation of the Fourteenth Amendment's privileges and immunities clause that gave Congress power to legislate on the rights of person and property protected under Article IV would vastly expand Congressional power, and Miller argued that the clause should not have that effect. ${ }^{49}$

According to Justice Miller, a fundamental rights construction of the Fourteenth Amendment "radically changes the whole theory of the relations of the State and Federal governments to each other and of both these governments to the people," ${ }^{\circ \circ}$ and it should not be adopted unless the language was clear. Fundamental rights, such as the right to pursue an occupation, belong to the citizen of a state only in his capacity as a state citizen, and "they are left to the State governments for security and protection, and not by this article placed under the special care of the Federal government." ${ }^{51}$ Therefore the plaintiff butchers had no rights under the Fourteenth Amendment privileges and immunities clause.

\section{B. The Dicta's Ambiguity on Incorporation of the Bill of Rights}

Having rejected a fundamental rights interpretation, Justice Miller offered dicta on the substance of the clause: "[L]est it should be said that no such privileges and immunities are to be found if those we have been considering are excluded, we venture to suggest some which owe their

44. Id.

45. Id. at 74 .

46. Id. at $74-75,8 \mathrm{I}$.

47. Id. at $80-81$.

48. Id.

49. Id. at $77-78$.

5o. Id. at 78 .

5I. Id. 
existence to the Federal government, its National character, its Constitution, or its laws." 52

All of the privileges and immunities Miller then mentioned had their source outside the clause. Almost all seemed unaffected by the adoption of the Amendment: the right to travel, to the protection of the federal government abroad, to use navigable waters, and to obtain rights under treaties were recognized before the Amendment. ${ }^{53}$ Other privileges were secured by the Thirteenth, Fourteenth, and Fifteenth Amendments with no suggestion that the privileges or immunities clause had any effect on their substance. Only one phrase in Miller's list of the privileges and immunities of national citizenship had any potential for a substantive impact. Justice Miller stated: "The right to peaceably assemble and petition for redress of grievances, the privilege of the writ of habeas corpus, are rights of the citizen guaranteed by the Federal Constitution." 54

The right of assembly and petition is stated in the First Amendment: "Congress shall make no law... abridging ... the right of the people peaceably to assemble, and to petition the government for redress of grievances." 55 This recognizes the existence of the right, but operates only to limit Congress. Habeas is mentioned in Article I, section 9, which provides: "The Privilege of the Writ of Habeas Corpus shall not be suspended, unless when in Cases of Rebellion or Invasion the public Safety may require it.. ${ }^{16}$ The placement of the clause in Section 9 demonstrates that it only applies to the federal government. ${ }^{57}$ Justice Miller's reference to these rights did not mention that the Constitution only limited their impairment by the federal government.

There are at least three ways to interpret Miller's references to the right of peaceable assembly and habeas corpus: (I) as an acknowledgment of the status quo, (2) as privileges found in the structure of federalism, or(3) as concrete instances of natural rights. First, Miller's reference to the constitutional provisions could mean that the privileges and immunities clause recognized the status quo and simply preserved it. The constitutional rights mentioned were privileges, but their scope was un-

52. Id. at 79. In the remainder of the opinion, Miller disposed of the due process and equal protection arguments. He said that regulation of trade was not a deprivation of property under the due process clause, and that equal protection was primarily concerned with discrimination against African Americans and plaintiffs failed to make a strong case to have it apply to their situation. Id. at $79-83$.

53. Id. at $79-80$. E.g., Crandall v. Nevada, 73 U.S. (6 Wall.) 35, 49 (I867) (right to travel); Gibbons v. Ogden, 22 U.S. ( 9 Wheat.) I, I97 (I824) (use of navigable waters within state); Fairfax's Devisee v. Hunter's Lessee, II U.S. (7 Cranch) 603, 627 (I8I3) (rights under treaties).

54. Slaughter House Cases, 83 U.S. (I6 Wall.) at 79.

55. U.S. Const. amend. 1.

56. U.S. Const. art. I, \& 9 .

57. Slaughter-House Cases, 83 U.S. (16 Wall.) at 74-75. 
changed. Second, the phrase could refer to the right to petition the federal government or to bring habeas corpus in federal court, rights with which states could never interfere. These rights are implicit in the federal structure created by the Constitution, regardless of any specific express language. If so, their mention implied nothing about the application of other constitutional provisions to the states. Third, the reference could mean that the abstract right protected against federal interference was now protected from abridgment by the state. In other words, the right existed as natural law apart from the Constitution, and its mention in the Constitution made that general principle a privilege of United States citizenship.

\section{Declaring the Status Quo}

The most natural understanding of habeas corpus, assembly, and petition as "rights of the citizen guaranteed by the Federal Constitution" is that they refer to the rights defined by the Constitution. ${ }^{8}$ If rights "owe their existence" to the Constitution, the Constitution determines their scope. ${ }^{59}$ No other constitutional rights were altered by inclusion in Miller's list of privileges or imınunities. ${ }^{60}$ Thus, the natural inference is that Miller was listing the privileges of national citizenship that existed when the amendment was adopted, not changing their substance.

Justice Miller did not quote the Constitution exactly when he said the rights "were guaranteed by the Federal Constitution." "The right to peaceably assemble and petition for redress of grievances" was a short form of "the right of the people peaceably to assemble and petition the government for redress of grievances." ${ }^{.62}$ There is no reason to believe that Miller thought the right extended beyond petitioning the government to reach petitioning private individuals. Similarly, his reference to the writ of habeas corpus did not mention suspension in cases of rebellion and invasion. ${ }^{63}$ The failure to quote the entire clause is no indication that he thought the privilege or immunities of citizens of the United States with respect to habeas corpus extended further than the stated limits in Article I, section 9. ${ }^{64}$ Since Miller's language is a shorthand reference to rights whose substance is found in the Constitution, the limits there would seem to be the extent of the privilege or immunity.

\footnotetext{
58. Id. at 79 .

59. Id.

60. Id. at $79-82$.

61. Id. at 79 .

62. Id.

63. Id. at $79-80$.

64. Id. at 79.
} 
Confining the impact of the right to assemble and habeas corpus to limits on the federal government is consistent with other rights on Miller's list of the privileges and immunities of citizens of the United States. He included privileges relevant to the federal government alone, e.g., "to demand the care and protection of the Federal government over his life, liberty, and property when on the high seas or within the jurisdiction of a foreign government. ${ }^{\text {} 65}$ The Fourteenth Amendment prohibition against state denial of the privileges or immunities of citizens of the United States surely did not mean that states must afford care and protection to citizens abroad. The right to protection abroad remained only a right to have federal protection. Similarly, Miller's mention of the rights of assembly and habeas corpus may simply refer to examples of existing privileges of citizenship without altering their character from restrictions of federal power to restrictions of state power.

The "right of citizenship guaranteed by the Federal Constitution" is only against the federal government. Congress shall not abridge the right of assembly and petition, and the federal government will not suspend the writ of habeas corpus. Under Section 5 of the Fourteenth Amendment, Congress could enact laws to prevent states from attempting to force the federal government to suspend the writ of habeas corpus or to take action against peaceable assembly. ${ }^{67}$ The privileges and immunities clause under this interpretation simply declared the status quo. It made express what had always been implicit in the supremacy clause-that states could not abridge the privileges or immunities of citizens of the United States - and it reinforced congressional power to protect them.

\section{Noncommital Structural Rights}

According to the status quo interpretation, Justice Miller listed habeas and petition because they were in the Constitution. Alternatively, Miller may have chosen them because they were based on access to the federal government. ${ }^{68}$ He did not mention such prominent rights as freedom of speech, freedom of religion, warrant requirements, or even trial by jury, which have constitutional protection only by inclusion in the text. ${ }^{\text {kg }}$ Instead, he referred to two rights that had a dual nature. Both habeas and petition were inherent in the federal structure so that states

65. Id.

66. Id. at 79 .

67. U.S. Const. amend. XIV, § 5 .

68. Richard L. Aynes, Constricting the Law of Freedom: Justice Miller, The Fourteenth Amendment, and the Slaughter-House Cases, 70 ChI.-Kent L. Rev. 627, 654 (1994); RoberT Kaczorowski, The Polttics of Judicial Interpretation: The Federal Courts, Department of Justice and Civil RighTs, I866-I 876, at I52 (John H. Baker et al. eds., Oceana Publications, Inc. 1985).

69. See Slaughter-House Cases, 83 U.S. (16 Wall.) at 79-80. 
could not interfere with them, and expressly protected by the Constitution against federal interference. They provided a transition into a list of rights that other clauses of the Constitution, including the Civil War amendments themselves, specifically applied against state governments.

The right to assemble and petition government is not limited to federal access today, but the Supreme Court had not definitively interpreted the right when Miller wrote Slaughter-House. The First Amendment applied only against the federal government, and federal interference with petitions to state or local government would not have been a plausible exercise of federal power. Thus, the First Amendment right of the people peaceably to assemble and to petition the government for redress of grievances might reasonably have been interpreted to refer to assembly for the purpose of petitioning the federal government. However, as the Court said only a few years later, the right to petition the federal government for redress of grievances is a privilege or immunity of federal citizenship that does not depend upon any express constitutional provision. ${ }^{70}$ State interference affects access to the federal government, which abridges a privilege of citizens of the United States under the reasoning used in Crandall v. Nevada."

Miller referred to assembly and petition and habeas immediately after discussing two rights that are derived from the structure of the Constitution and not from specific constitutional provisions-the right to travel and the right to federal protection while abroad. ${ }^{72}$ Both rights were based on the citizen's relationship to the institutions of the federal government. If assembly is part of the process of petitioning the federal government for redress of grievances, the right is both inferred from the structure of government and protected by the First Amendment. If the writ of habeas corpus is basic to vindication of federal rights, it might also be inferred from the supremacy clause as well as its mention in Article I. Indeed, in prohibiting the suspension of the writ, Article I assumes its existence.

The federal access interpretation is linguistically possible, but it is less persuasive than the status quo view. The passage seems to make the point that the rights are privileges because the Constitution guarantees them. Further, the Court intimated only a few years later that the First

70. United States v. Cruikshank, 92 U.S. 542,552 ( 1876 ).

7I. 73 U.S. (6 Wall.) 35, 49 (I867) (holding that a tax on leaving the state was unconstitutional because it interfered with the right of citizens to access the institutions of the federal government).

72. Slaughter-House Cases, 83 U.S. (16 Wall.) at 79. Even if Miller identified the right of assembly entirely with the First Amendment, that would not suggest that he believed the Fourteenth Amendment altered the impact of the First. It would simply point to a status quo reading. $C f$. Palmer, supra note 8 , at $75^{0}-5 \mathrm{I}$. 
Amendment right was broader than access to petition the federal government. ${ }^{73}$ Nevertheless, the choice of petition and habeas from among all the other rights contained in the Constitution suggests that Miller did not mean that the privileges or immunities clause of the Fourteenth Amendment altered the scope of any existing privilege. On the other hand, the choice of constitutional rights that were enforceable against the states does not exclude the possibility of incorporation.

\section{Incorporation}

The third interpretation of Miller's opinion is that reference to a right in the Constitution made the abstract right a privilege or immunity of federal citizenship that states could not abridge. Miller did not expressly mention the restricted scope of the constitutional rights he mentioned. Substituting Miller's description as one specific instance of the general phrase, the Fourteenth Amendment would read, "no state shall make or enforce any law which shall abridge "the right to peaceably assemble and petition for redress of grievances."

The main attraction of reading Miller's opinion to refer to a generalized right of assembly and petition as a privilege of citizenship of the United States is that it is closer to the framers' intention for the privileges and immunities clause than an interpretation that renders the provision a tautology. The main problem is that this reading conflicts with the opinion's thrust.

Justice Miller never expressly said that the privileges and immunities clause incorporated the Bill of Rights. Two separate and apparently inconsistent things must be true in order to infer that he intended his opinion to support incorporation. First, his references to habeas and peaceable assembly and petition must refer to the rights specified in the Constitution and must depend upon that mention for their existence as a privilege or immunity. Otherwise, their mention offers no support for applying to the states any other constitutional restrictions on the federal government. ${ }^{74}$ Second, Miller's reference must be to an abstract right of assembly and petition free from limits of the actual constitutional right. Otherwise, it offers no support for altering the privilege from a limit on the federal government to a limit on the state. But despite the difficulties of this reading of the clause, it is at least possible linguistically.

73. Cruikshank, 92 U.S. at $55 \mathrm{I}$.

74. It is probably true that the reference is the right specified in the Constitution, but, as the previous subsection shows, it is not necessarily so. 


\section{Whether the Ambiguity Was Deliberate?}

It is possible that Miller had no firm intention with respect to incorporation. He felt compelled to say something about the content of the privileges and immunities of citizens of the United States, but his comments were all dicta. The opinion drew plenty of fire for its rejection of fundamental rights: a little strategic ambiguity on incorporation would not be a bad idea. Professor James Fox has argued that the ambiguity of the dicta gave Miller and the court time to more fully consider the issue of incorporation at another day. ${ }^{75}$ There is no "smoking gun" to prove that the majority wanted to be ambiguous. The argument that the ambiguity was intentional focuses on the existence of ambiguity, the failure of the analysts to discuss the issue, and the lack of any necessity to resolve the issue. The idea of deliberate ambiguity with respect to incorporation gains some support from the treatment of the opinion by scholars of the time who seemed to see it as merely confirming their own ideas.

The incorporation aspect of the Slaughter-House Cases was of little interest to contemporaries reacting to the decision. The crucial issue was that the distinction between privileges of federal and state citizenship made the Fourteenth Amendment privileges or immunities clause inapplicable to fundamental rights of citizenship including property and contract. Any discussion of incorporation was dicta. Academic reaction focused on the majority's rejection of fundainental rights of citizenship, and paid no attention to what that rejection meant for incorporation.

Some reports merely noted or quoted from the case without significant comment. ${ }^{76}$ Others commented only on the fundamental rights holding and ignored any implication the opinion might have had with respect to incorporation. The Nation supported the decision, but focused on the difference between the dissenters and the majority with respect to a fundamental rights interpretation of the clause. ${ }^{77}$ William Royall roasted the court in the Southern Law Review for failing to pay attention to congressional debates. ${ }^{78}$ Royall's article buttresses the contention that contempo-

75. Fox, supra note 6, at 79-80; see also TrIBE, AMERICAN CONSTITUTIONAL LAw, supra note 9, at 1307.

76. Summary of Events: United States, 7 AM. L. Rev. 732, 742 ( 1873 ).

77. The Supreme Court Righting Itself, I6 NATION 280 (Apr. 24, I873), cited in VI Charles FaIRman, History of THE Supreme Court of THE UNITEd States: Reconstruction and Reunion i 864-88, Part ONe, at I37I (Oliver Wendell Holmes Devise, Macmillan 197I). In Monopolies and the Fourteenth Amendment, ro NATION 36I, 362 (Dec. I, I870), the editors had expressed dismay at the Circuit Court decision in the case that would have invalidated thc Louisiana Law.

78. See generally William Royall, The Fourteenth Amendment: The Slaughter House Cases, 4 S. L. REv. 558 ( 1878 ). Charles Fairman claimed that Royall's writings were intended to use the amendment to oppose Republican domination and in particular to back bondholders against a movement to repudiate Virginia state debt. FAIRMAN, supra note 77, at 137 I-74. 
raries thought that the privileges and immunities clause of the Fourteenth Amendment guaranteed fundamental rights, but it provides no support for believing that Miller's opinion advanced that cause. ${ }^{79}$ All these articles simply ignored the significance, if any, of Miller's reference to habeas corpus, assembly and petition as privileges of United States citizenship.

The declaratory status quo interpretation of Miller's opinion received some support from the writings of Thomas Cooley. The third edition of his Treatise on the Constitutional Limitations ( 1874 ) referred to the understanding that the Bill of Rights applied only to the federal government. A footnote stated, as it had in the I87I edition:

For instance, though the right of trial by jury is preserved by the Constitution of the United States, the States may, nevertheless, if they choose, provide for the trial of all offences against the States, as well as the trial of civil cases in the State courts, without the intervention of a jury. ${ }^{80}$

Elsewhere in the book, he noted that the Fourteenth Amendment "received a very careful examination at the hands of the Supreme Court" in the Slaughter-House Cases. ${ }^{81}$ Cooley's attention to that opinion without suggesting any change in his jury trial note intimates that he thought Miller did not support incorporation. ${ }^{82}$ By the next edition in 1878 , the Court's rejection of incorporation was clearer, and the footnote language was moved directly into the text. ${ }^{83}$

Unlike Cooley, John Norton Pomeroy thought that the federal government ought to be able to prevent the states from violating the principles of the Bill of Rights. He said in his Introduction to the Constitutional Law of the United States that the Fourteenth Amendment would enable the federal government to do precisely that. ${ }^{84}$ After the decision in the Slaughter-House Cases, he left this prior discussion untouched, and asserted in an appendix that "[i]n no instance has any proposition or doctrine stated in the text been expressly declared erroneous and rejected by

79. See Royall, supra note 78.

80. Thomas M. Cooley, Treatise on the Constitutional Limitations Which Rest upon the Legislative Power of the States of the American Union i9, n.i (3d ed. 1874).

8I. Id. at 294 n.2.

82. Cooley also noted in his revised fourth edition of Story's Commentaries on the Constitution that his views were "fortunately in harmony" with Miller's opinion in Slaughter-House. 2 JoSEPH Story, Commentaries on the Constitution of the United States 693 (Thomas M. Cooley ed., Little Brown 4th ed. 1873) (1833). See discussion in Wildenthal, supra note 8, at I 130-33.

83. Thomas M. Cooley, Treatise on the Constitutional limitations Which Rest upon the Legislative Power of the States of the American Union 25 (4th ed. I878).

84. John Norton Pomeroy, AN lntroduction to the Constrtutional Law of the United States I5I, at $\$ 237(1870)$. 
the Supreme Court of the United States ... ." ${ }^{85}$ Nevertheless, his discussion of the Slaughter-House Cases suggests that he did not see in it an endorsement of incorporation. After paraphrasing Miller's explication of the two sets of privileges and immunities, state and federal, in which the fundamental rights of state citizens remain matters for the state alone, Pomeroy wrote: "Nor does the amendment purport to define, much less to create any 'privileges or immunities' which are peculiar to national citizenship. The Court forbears to enumerate these privileges and immunities and the opinion upon this particular subject is very unsatisfactory. ${ }^{186} \mathrm{He}$ insisted that the dissenters were correct in viewing privileges and immunities as the fundamental rights of citizens, and they would eventually carry the day. ${ }^{87}$ Miller had not "expressly declared erroneous" the proposition that the federal government could enforce the rights in the Bill of Rights against the states, but Pomeroy does not suggest that Miller supported it. ${ }^{88}$ Pomeroy rejected Miller's approach and criticized its failure to enumerate privileges of national citizenship despite Miller's list of such privileges. ${ }^{89}$

In sum, scholars writing about the opinion immediately after the decision paid little attention to whether the dicta implicitly supported or rejected incorporation. Cooley and Pomeroy took opposing positions on incorporation and the Slaughter-House Cases did not cause them to change their text, but neither author explicitly worked through how the opinion affected incorporation. The scholars' confusion and inattention to the incorporation issue supports the contention that the opinion was ambiguous, but it falls far short of showing that the ambiguity was deliberate.

\section{Slaughter-House Two: Slaughter-House Cases Rendered the Privileges and Immunities Clause Redundant}

The initial academic uncertainty about the impact of the SlaughterHouse Cases on incorporation was not reflected in the Court. From the dissents in the decision itself to the use of the case in subsequent opinions, the Court has consistently interpreted the Slaughter-House Cases to deny that the privileges or immunities clause incorporated the Bill of Rights. The opinion's arguable ambiguity flows from the biases of its readers and not the intention of its author. Most commentators have ac-

85. John Norton Pomeroy, An Introduction to the Constrtutional Law of the Untted States $519 \$ 76$ I (New York, Hurd \& Houghton 3d ed. 1876).

86. Id. at $527 \& 705$.

87. Id. at $532 \S 767$.

88. Id. at $53^{\circ}-3$ I $\$ 767$.

89. $I$ d. at $531 \S 767$. 
cepted this view of the decision, and complained that it renders the privileges or immunities clause useless..$^{90}$

The Court's position denies any independent force to the clause. If all privileges or immunities are derived from sources other than the clause, states could not abridge them even if the clause did not exist. Professor William Rich has argued that recognition of privileges and immunities in Section I is not useless because it is a vehicle for the exercise of congressional power to enforce privileges or immunities under Section $5 .^{91}$ Rich contends that this overcomes the new federalism decisions on state sovereign immunity. ${ }^{92}$ However, it seems unlikely that a Court that finds sovereign immunity implicit in the Constitution will change its views when presented with a privileges or immunities argument. Thus, the conventional view and current doctrine make the privileges and immunities clause of the Fourteenth Amendment largely redundant.

\section{A. The Dissenters' Critique: "A vain and idle enactment"93}

Justice Stephen J. Field dissented vigorously in the Slaughter-House Cases, joined by Chief Justice Salmon P. Chase and Justices Joseph Bradley and Noah Swayne. ${ }^{94}$ Justice Field insisted that the privileges and immunities of citizenship were the fundamental rights of citizens of all free countries, rights mentioned in the Civil Rights Act, referred to by Article IV, and described by members of Congress during the debates. ${ }^{95}$ The monopoly's exclusion of the plaintiff butchers from the slaughterhouse business denied them equality of rights in a fundamental area. ${ }^{96}$ Field castigated Miller's majority opinion for stripping the privileges and immunities clause of any force:

If this ... only refers, as held by the majority of the court in the opinion, to such privileges and immunities as were before its adoption specifically designated in the Constitution or necessarily implied as belonging to citizens of the United States, it was a vain and idle enactment, which accomplished nothing, and most unnecessarily excited Congress and the people on its passage. With privileges and immunities thus designated or implied no State could ever have interfered by

90. See Aynes, supra note 68, at 686.

91. Rich, Privileges or Immunities, supra note 6, at 304; Rich, Taking "Privileges or Immunities" Seriously, supra note 6, at 159.

92. Acceptance of the privileges or immunities argument would change the result in Seminole Tribe of Fla. v. Florida, 5 I7 U.S. 44 (1996), City of Boerne v. Flores, 521 U.S. 507 (1997), Fla. Prepaid Postsecondary Educ. Expense Bd. v. Coll. Sav. Bank, 527 U.S. 627 (I999), Alden v. Maine, 527 U.S. 706 (1999), Kimel v. Fla. Bd. of Regents, 528 U.S. 62 (2000), and Bd. of Trs. of Univ. of Ala. v. Garrett, 531 U.S. 356 (200I).

93. Slaughter-House Cases, 83 U.S. (I6 Wall.) 36, 96 ( 1872 ) (Field, J., dissenting).

94. Id.

95. Id. at 95 (Field, J., dissenting).

96. Id. at 90-9I (Field, J., dissenting). 
its laws, and no new constitutional provision was required to inhibit such interference. The supremacy of the Constitution and the laws of the United States always controlled any State legislation of that character. $^{97}$

Critics who urge an incorporation reading of the majority opinion dismiss Field's attack on the grounds that he was just reacting to Miller's rejection of fundamental rights. ${ }^{98}$ However, Field's language ("a vain and idle enactment, which accomplished nothing") strongly supports the view that Miller wrote a status quo opinion. ${ }^{99}$

As Justice Field explained in his dissent, the framers believed that "privileges or immunities of citizens of the United States" described the inherent fundamental rights of citizens with respect to government, so that the prohibition on state abridgment made the rights legally binding. ${ }^{100}$ The amendment was to convert an "ought" into an "is." The language worked because the rights applied to the states before the amendment, although they were not legally enforceable. There was no change in the definition of privileges of citizens of the United States, only a change in whether they were enforceable.

Without a fundamental rights interpretation, however, incorporation does not work linguistically. Incorporation converts a right against the federal government into a right against the state that the federal government can enforce. There was no privilege or immunity of citizens of the United States to be free of state restrictions on assembly and petition prior to the Fourteenth Amendment; but, according to incorporation theory, prohibiting the states from abridging the privileges or immunities

97. Id. at 96 (Field, J., dissenting).

98. John Hart Ely, Democracy and Distrust: A Theory of Judicial Review 196 n.59 (i98o).

99. Bryan Wildenthal suggested that when Field said "grants of exclusive privileges ... are opposed to the whole theory of free government, and it requires no aid from any bill of rights to render them void," he was accusing Miller and the majority of relying on the Bill of Rights as a referent for the scope of privileges and immunities. Wildenthal, supra note 8, at 1095 . The phrase followed Field's condemnation of the majority for upholding a law that failed to recognize the equality of right in lawful pursuits. Thus, Wildenthal infers that Field thought Miller required the Bill of Rights to be applicable in order to find state action void. However, Field was quoting from an opinion of the Supreme Court of Connecticut that invalidated a state grant of a monopoly despite the absence of any direct constitutional provision against it, and the words which follow "Bill of Rights" in that opinion are "the first section of which declares that 'no man or set of men, are entitled to exclusive pubhic emoluments, or privileges from the community,' to render them void." Norwich Gas Light Co. v. Norwich City Gas Co., 25 Conn. 19, 38 (1856). Thus, the "Bill of rights" in the cite was not the federal one but the declaration in Connecticut. Perhaps Field intended to shift the sense of the word in his paraphrase of the Connecticut court in order to allude to the doctrine of incorporation, but it is far more likely that he simply used the quote to illustrate his position that privileges or immunities were fundamental rights derived from natural law. This leaves us with Field's sweeping condemnation of the majority opinion for rendering the privileges and immunities clause a nullity.

100. Slaughter-House Cases, 83 U.S. (16 Wall.) at 93 (Field, J., dissenting). 
of citizens of the United States made it one. That would create something from nothing. Justice Field's stinging dissent demonstrates that he and the dissenters who joined him did not believe that Justice Miller and the majority were attempting such alchemy. ${ }^{101}$

Justice Bradley also wrote a separate dissenting opinion with which Justice Swayne concurred. Bradley insisted that pursuit of an employment was a privilege of citizenship and the monopoly unreasonably abridged it. ${ }^{102} \mathrm{He}$ argued that the state could regulate fundamental righis, but could not subvert them. ${ }^{103}$ Bradley was very specific that these fundamental rights included restrictions against government found in the Constitution:

The Constitution, it is true, as it stood prior to the recent amendments, specifies, in terms, only a few of the personal privileges and immunities of citizens, but they are very comprehensive in their character. The States were merely prohibited from passing bills of attainder, ex post facto laws, laws impairing the obligation of contracts, and perhaps one or two more. But others of the greatest consequence were enumerated, although they were only secured, in express terms, from invasion by the Federal government; such as the right of habeas corpus, the right of trial by jury, of free exercise of religious worship, the right of free speech and a free press, the right peaceably to assemble for the discussion of public measures, the right to be secure against unreasonable searches and seizures, and above all, and including almost all the rest, the right of not being deprived of life, liberty, or property, without due

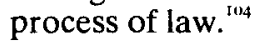

Although Bradley noted rights protected "in express terms" only against the federal government, he indicated that all the privileges and immunities applied against the states because they were fundamental. ${ }^{105}$ He said "even if the Constitution were silent, the fundamental privileges and immunities of citizens, as such, would be no less real and no less inviolable than they now are." ${ }^{106}$ Thus, incorporation for Justice Bradley was based on the fundamental rights theory that Miller's opinion for the majority repudiated.

Finally, Justice Swayne wrote separately in addition to concurring in the dissents of both Field and Bradley. He left the application of principle primarily to their dissents, but he was anxious to add his own statement of regret about the decision. Swayne began his remarks by distinguishing "privileges and immunities" of citizens of a state and citi-

IoI. See id. at 83 (Field, J., dissenting).

I02. Id. at I I6 (Bradley, J., dissenting).

104. Id. at 118 (Bradley. J., dissenting).

I05. Id. (Bradley, J., dissenting).

106. Id. at I 9 (Bradley, J., dissenting). 
zens of the United States in terms that looked similar to those Miller used. ${ }^{107}$ But the resemblance was only superficial. ${ }^{108}$ Swayne said "the privileges and immunities of a citizen of the United States include, among other things, the fundamental rights of life, liberty, and property, and also the rights which pertain to him by reason of his membership of the Nation." ${ }^{\text {rog }}$ By finding fundamental rights were privileges of citizens of the United States, Justice Swayne made a critical turn that Justice Miller did not. Swayne's distinction was primarily between the particular and the abstract. State law (statutory and constitutional) was the concrete embodiment of fundamental rights. Property may be a fundamental right, but the specific rules for recognizing property rights are matters of local law. If the rules were consistent with fundamental rights, the Fourteenth Amendment did not change them or give Congress power to change them. But if the state law violated fundamental rights, Swayne would hold it unconstitutional.

Justice Swayne specifically criticized the majority for failing to make the limits against the federal government applicable to the states. ${ }^{\text {II }}{ }^{\mathrm{He}}$ said that the majority opinion

turns what was meant for bread into a stone. By the Constitution, as it stood before the war, ample protection was given against oppression by the Union, but little was given against wrong and oppression by the States. That want was intended to be supplied by this amendment. Against the former this court has been called upon more than once to interpose. Authority of the same amplitude was intended to be conferred as to the latter. But this arm of our jurisdiction is, in these cases, stricken down by the judgment just given.

I07. Justice Swayne noted:

All those which belong to the citizen of a state except as to bills of attainder, ex post facto laws, and laws impairing the obligation of contracts, are left to the guardianship of the bills of rights, constitutions, and laws of the States respectively. Those rights may all be enjoyed in every State by the citizens of every other State by virtue of clause 2 , section 4 , article 1, of the Constitution of the United States as it was originally framed. This section does not in anywise affect them; such was not its purpose.

Id. at 1 26-27 (Swayne, J., dissenting).

I08. Bryan Wildenthal suggests that Swayne's dissent supports an incorporationist reading of the majority opinion because his dual privileges analysis followed Miller, yet he joined Bradley's opinion which explicitly found the privileges and immunities clause included provisions from the Bill of Rights. Wildenthal, supra note 8, at I 104-105. This misses Swayne's statement that fundamental rights are federal privileges or immunities. By joining Justice Bradley, Swayne divided privileges of state citizenship and national citizenship in a manner radically different from Justice Miller, because Justice Bradley insisted that the Bill of Rights were privileges and immunities under the Fourtcenth Amendment because they were fundamental rights and not because they were mentioned in the Constitution.

109. Slaughter-House Cases, 83 U.S. (16 Wall.) at 126 (Swayne, J., dissenting).

II0. Id. at 129 (Swayne, J., dissenting).

II I. Id. at 130 (Swayne, J., dissenting). 
In sum, the dissenters agreed that Miller had rejected fundamental rights. Justice Bradley believed that provisions of the Bill of Rights were among the fundamental rights that the privileges and immunities clause should have protected, but joined with Swayne and Chase in Field's dissent castigating Miller for making the amendment into a "vain and idle enactment, which accomplished nothing." tacked Miller for failure to find in the clause the same power to restrain the states that existed to restrain federal action.

If Miller was replying to the dissent, he could have said plamly that the clause made the limits on the federal government applicable to the states. That would have responded directly to Swayne and given the lie to Field's accusations. In light of their criticism, Miller's failure to state expressly that the clause incorporated the Bill of Rights against the states is powerful evidence that he thought it did not.

\section{B. Subsequent Decisions: Slaughter-House Cases as Precedent for a Status Quo Ante Interpretation}

The best evidence of Miller's meaning is the view he and the other justices in the majority subsequently took of the case and the issues in it. After the adoption of the Fourteenth Amendment, when the Court considered the application of the original amendments to the states, it held they did not apply. ${ }^{113}$ When parties used the Fourteenth Amendment to claim rights that were enumerated in the original amendments to the Constitution, the Court reasoned that such rights were fundamental rights of citizenship, and not ones relating to national government structure. ${ }^{114}$ This used Slaughter-House reasoning to deny incorporation, and soon the Court began to cite Slaughter-House for that purpose.

Before the Slaughter-House Cases, the Court had held unanimously that it lacked appellate jurisdiction over a claimed violation by a state of the Fifth and Sixth Amendments, because those amendments did not apply to state government. ${ }^{115}$ Counsel in Twitchell $v$. Pennsylvania ${ }^{116}$ failed to raise the newly enacted Fourteenth Amendment, so the Court was not

I I 2. Id. at 96 (Field, J., dissenting).

1 13. See infra notes I 17, I 18, I24, 219 and accompanying text discussing Twitchell v. Pennsylvania, 74 U.S. (7 Wall.) 32 I (1868); see infra notes I I9-23 and accompanying text discussing Edwards v. Elliot, 88 U.S. (2 I Wall.) 532 (I874); see infra notes I26, I27 and accompanying text discussing Walker v. Sauvinet, 92 U.S. 90 ( 1876$)$.

I 14. See infra notes 128-37 and accompanying text discussing United States v. Cruikshank, 92 U.S. $542(1876)$.

I 5. See infra notes I 6-I8, I 24, 219 and accompanying text discussing Twitchell, 74 U.S. (7 Wall.) at $32 \mathrm{I}$.

1 I6. 74 U.S. (7 Wall.) at $321-27$. 
squarely presented with the incorporation issue. ${ }^{117}$ Nevertheless, if members of the Court thought the new Amendment made the others applicable to the states, it seems surprising that they would allow Twitchell's execution on the basis that the Fifth and Sixth Amendments did not apply. ${ }^{118}$

The year after Slaughter-House, counsel cited it in Edwards v. Elli$o t t^{119}$ to show that the trial by jury was not a privilege or immunity of citizenship of the United States. The defendant contended inter alia that the state lien law conflicted with the right of trial by jury, saying it abridged a privilege or immunity of a citizen of the United States protected by the Fourteenth Amendment. ${ }^{120}$ Unfortunately, the record did not indicate that this challenge had been specifically made in the courts below. ${ }^{121} \mathrm{Op}$ posing counsel, A.Q. Keasbey, said the argument was an afterthought and needed no reply. ${ }^{122}$ But then, citing the portion of the SlaughterHouse Cases discussing the fundamental rights of citizens under Article IV, Keasbey said:

[T] he constitutional provisions referred to did not profess to control the power of the State governments over the rights of its own citizens, but only to declare that as the States grant them to their own citizens ...the same, neither more nor less, shall be the measure of the rights of citizens of other States within their jurisdiction. ${ }^{123}$

In other words, the right to trial by jury and other protections of the Bill of Rights were fundamental rights applicable to citizens as citizens of a state through Article IV and not privileges of U.S. citizenship except against violation by the federal government and except as protected by Article IV.

Justice Nathan Clifford, a member of the Slaughter-House majority, found that the federal constitutional issue was not raised below in state court, and he rejected the defendant's argument for that reason. How-

I 17. Id. at 513-14.

I 8. Twitchell actually committed suicide in his cell on the day set for execution. Philadelphia Timeline, i868 (excerpted from Rudolph J. Walther, Happenings in Ye Olde Philadelphia, I680I900 (1925)), http:/www.ushistory.org/philadelphia/timeline/I868.htm. Justice Joseph Bradley joined the court after $T$ witchell, and his separate dissent was the only opinion in Slaughter-House to say expressly that provisions of the amendments were applicable to the states. 83 U.S. (16 Wall.) $36,1_{18-19}$ (I872).

I I9. 88 U.S. (2I Wall.) 532,549 (I874).

120. "The State law in effect takes away or obstructs the right of trial by jury, and so abridges one of 'the privileges or immunities of citizens of the United States.' ... These matters all fall within the fourteenth amendment." Id. at 544 (argument of D. McMahon for plaintiff in error).

121. The defendant's primary argument, however, was that a lien on a ship being built was a maritime lien and that states had no jurisdiction over such liens. Id. at 541 .

I22. Id. at 548 .

123. Id. at 548-49 (argument of A.Q. Keasbey). 
ever, Clifford also said for a unanimous court that the Seventh Amendment does not apply to trials in state court, citing Twitchell ${ }^{124}$ as well as cases decided prior to the Fourteenth Amendment, and Cooley's Treatise on Constitutional Limitations. ${ }^{125}$

Two years later in Walker $v$. Sauvinet, ${ }^{126}$ Chief Justice Morrison Waite cited Edwards for the proposition that the right to trial by jury in the Seventh Amendment applied only to trials in federal court:

The States, so far as this amendment is concerned, are left to regulate trials in their own courts in their own way. A trial by jury in suits at common law pending in the state courts is not, therefore, a privilege or immunity of national citizenship, which the States are forbidden by the Fourteenth Amendment to abridge. ${ }^{127}$

Waite made it clear that his analysis was consistent with the Slaughter-House Cases when he wrote United States v. Cruikshank ${ }^{128}$ later that year. "The same person may be at the same time a citizen of the United States and a citizen of a State, but his rights of citizenship under one of these governments will be different from those he has under the other. Slaughter-House Cases, I6 Wall. 74." 129

Chief Justice Waite focused on whether the federal government had power to legislate against private acts of violence interfering with assembly or carrying weapons. He characterized the right of the people to assemble as "one of the attributes of citizenship under a free government." ${ }^{30}$ Under the reasoning of Slaughter-House, ${ }^{131}$ a fundamental right of that nature would be a privilege of state citizenship and not federal citizenship. Waite discussed the constitutional provisions of the Bill of Rights prior to the Civil War as restraints on Congress. The right of assembly was not guaranteed by the First Amendment "except as against congressional interference," and the power to protect the fundamental right of assembly was placed in the states and "has never been surrendered to the United States." ${ }^{32}$ Congress would have power to protect freedom of assembly only if the assembly and petition related to Congress itself or was otherwise connected to performance of national duties. Thus, protection in petitioning Congress was a privilege of United States citizenship, but not because it was mentioned in the Constitu-

I24. 74 U.S. (7 Wall.) 32 I (I868).

I25. Edwards, 88 U.S. at 532,557 ; see discussion of CooLEY supra text accompanying notes $80-83$.

I26. 92 U.S. 90 ( 1876$)$.

I27. $I d$. at 92.

128. 92 U.S. 542 ( 1876$)$.

129. Id. at 549 .

I30. Id. at $55 \mathrm{I}$.

I3I. 83 U.S. 36 (1872).

132. Cruikshank, 92 U.S. at 552. 
tion. ${ }^{133}$ With respect to assembly generally, or bearing arıns, the federal government had no power to legislate against private action and only the states could act.

Although Chief Justice Waite had not been on the Court when Slaughter-House was decided, most of the other members of the Court, including Justice Miller, had been. If Miller thought that the Chief Justice had misread the case, he had the opportunity to clarify it. ${ }^{134}$ Instead, Justice Miller urged Waite to cite the Slaughter-House Cases to support the reasoning, and Miller specifically approved the opinion, joining Waite's opinions in both Cruikshank ${ }^{135}$ and Walker. ${ }^{136}$

Professor Robert Palmer saw Cruikshank as the critical decision, subjecting it to harsh criticism. ${ }^{137} \mathrm{He}$ argued that Cruikshank was an incorrect interpretation of the Slaughter-House Cases, and that Miller's silence about its misunderstanding of his opinion was due to the nature of

133. Kevin Newsom contended that Waite's discussion of the right of assembly showed that he supported incorporation, citing Waite's reference to "the right of the people peaceably to assemble for the purpose of petitioning Congress for the redress of grievances" as a reference to the First Amendment right. Newsom, supra note 8 , at 716 . However, the preceding paragraph of Waite's opinion described the amendment as a broader right.

[The amendment] assumes the existence of the right of the people to assemble for lawful purposes, and protects it against encroachment by Congress. The right was not created by the amendment; neither was its continuance guaranteed, except against congressional inter-

ference. For their protection in its enjoyment, therefore, the people must look to the States.

Cruikshank, 92 U.S. at 55I. Only after establishing that the right to assemble was not a privilege of national citizenship, did Chief Justice Waite discuss assembly for petitioning Congress for redress of grievances "or for anything else connected with the powers or the duties of the national government" as a privilege of national citizenship. $I d$. He then said that the idea of republican government implies a right of citizens to consult on public affairs. Id. Thus, Waite, in context, distinguished the First Amendment right that applied only against federal interference from a subset that applied to the states because they were derived froin the structure of government.

134. Field and Clifford dissented without opinion in Walker, 92 U.S. 90, 93 (1876), and Justice Clifford "dissented" in Cruikshank where he argued that the indictment was defective for failure to specify the privilege impaired, and did not get into the issue of whether Congress had power, 92 U.S. at 565-660. Since Clifford was the author of Edwards, it seems unlikely that his dissent with Fields in Walker related to the incorporation point. Field and Clifford were the only dissenters in Strauder $v$. West Virginia, 100 U.S. 303, 312 (1880), which struck down racial exclusion from jury service. This suggests that the motivation for the dissents was hostility to the state civil rights statute on which Walker was based. See Wildenthal, supra note 8 , at 1142 .

135. 92 U.S. at 542.

136. In a note to Justice Miller, Chief Justice Waite wrote:

1 thank you very much for calling my attention to my omission to refer to the Slaughter House cases. I am so little accustomed to citing cases as authority, except when I quote, that 1 too often omit it when I should not. It will give me pleasure to make the notation, which is certainly due. ... I am glad the opinion meets your approbation.

Waite Papers, quoted in 7 Charles fairman, History of the Supreme Court of the United States: Reconstruction and Reunion, i864-88, Part Two, 273-74 n.I53 (The Oliver Wendell Holmes Devise, Macmillan 1987) [hereinafter 7 Charles Fairman, History of the Supreme Court].

137. Palmer, supra note 8, at 762-69. 
the case. ${ }^{1{ }^{8}}$ Palmer noted that Slaughter-House dissenters Swayne, Bradley and Field, also chose not to dissent from Waite's opinion. ${ }^{139}$ But, in acquiescing to a holding on failure to allege state action, they could scarcely be expected to take issue with whether Waite correctly analyzed an opinion with which they disagreed. It was Justice Miller and the other members of the Slaughter-House majority who would be expected to speak up. Indeed, we know that Miller did speak up - to urge Waite to cite Slaughter-House and to give Waite's opinion his approbation. ${ }^{140}$

Two years later, in Davidson v. New Orleans, ${ }^{141}$ Justice Miller noted that the Slaughter-House Cases were primarily concerned with the privileges and immunities clause, and not due process. Counsel in Davidson pressed due process incorporation of the takings clause, but Miller rejected it. Miller also joined in Justice Woods's opinion in Presser v. Illinois ${ }^{142}$ which cited Cruikshank for the proposition that the right to bear arms applied only against the federal government and that the right peaceably to assemble was not a privilege of national citizenship except when petitioning the government. ${ }^{143}$ Thus, in every decision after the Slaughter-House Cases, the Court interpreted that decision to establish a framework for analysis that rejected incorporation through the privileges and immunities clause, and Justice Miller joined these opinions.

At the turn of the century in 1900, Slaughter-House was still the leading case on privileges and immunities, and the Court understood it to deny incorporation. In Maxwell v. Dow ${ }^{144}$ the defendant complained that his prosecution had been initiated by information instead of a grand jury indictment and that the state jury that convicted him had only eight members and was not the jury required by the Constitution. ${ }^{145}$ Justice Rufus Peckham said that this would have violated the constitutional guarantees if done by the federal government, but the rights were not privileges or immunities of national citizenship applicable against the states. ${ }^{146}$ He quoted extensively from the dual citizenship portion of the Slaughter-House opinion. After quoting Miller's list of privileges and immunities of national citizenship, Peckham said: "A right, such as is

\footnotetext{
I38. Id. at 769 .

139. Id.

I40. See FaIRman, supra note 136 and accompanying text.

I4I. 96 U.S. 97 ( 1878 ).

142. I I6 U.S. 252 (I886).

I43. I 6 U.S. at 265-69.

I44. I76 U.S. 581,606 (I900).

I45. Id. at 582 .

I46. Id. at $584-85$.
} 
claimed here, was not mentioned, and we may suppose it was regarded as pertaining to the State and not covered by the amendment."147

Granting the importance of the jury and the grand jury indictment, Peckham said these were issues for the state alone:

But, as said in the Slaughter-House Cases, the protection of the citizen in his rights as a citizen of the State still remains with the State. This principle is again announced in the decision in United States v. Cruikshank, wherein it is said that sovereignty, for the protection of the rights of life and personal liberty within the respective States, rests alone with the States. But if all these rights are included in the phrase "privileges and immunities" of citizens of the United States, which the States by reason of the Fourteenth Amendment cannot in any manner abridge, then the sovereignty of the State in regard to them has been entirely destroyed, and the Slaughter-House Cases and United States $v$. Cruikshank are all wrong, and should be overruled. ${ }^{148}$

In Twining $v$. New Jersey, ${ }^{149}$ Justice Moody focused analysis on the due process clause. ${ }^{\mathrm{I50}}$ As in the previous cases, he understood the rights stated in the Bill of Rights to be fundamental rights of citizens rather than rights arising out of the Constitution, and fundamental rights were not privileges or immunities of national citizenship:

If then it be assumed, without deciding the point, that an exemption from compulsory self-incrimination is what is described as a fundamental right belonging to all who live under a free government, and incapable of impairment by legislation or judicial decision, it is, so far as the States are concerned, a fundamental right inherent in state citizenship, and is a privilege or immunity of that citizenship only. Privileges and immunities of citizens of the United States, on the other hand, are only such as arise out of the nature and essential character of the $\mathrm{Na}$ tional Government, or are specifically granted or secured to all citizens or persons by the Constitution of the United States. ${ }^{\text {ISt }}$

Throughout the twentieth century, scholars and the Court continued to read Miller's opinion in Slaughter-House as a rejection of the incorporation theory. The Court has proceeded to use the due process clause to incorporate the Bill of Rights, while scholars carp that it should have been looking at privileges and immunities instead. ${ }^{\text {I5 }}$

I47. Id. at 59 I.

148. Id. at 593 (citation omitted).

149. 2 I I U.S. 78 (1908).

150. Id. at 106-14.

I5I. Id. at 97 .

152. Aynes, supra note 68, at 653-55; Michael Kent Curtis, Resurrecting the Privileges or Immunities Clause and Revising the Slaughter-House Cases Without Exhuming Lochner: Individual Rights and the Fourteenth Amendment, 38 B.C. L. REv. I, 7 I n.249 (1996). 


\section{The Function of the Privileges and Immunities Clause as a Basis for CONGRESSIONAL ENFORCEMENT}

Although critics complain that the status quo interpretation makes the clause useless, ${ }^{153}$ the congressional power to enforce privileges or immunities transforms it. The grant of power in Section 5 of the Fourteenth Amendment to enforce the other provisions of the article was very important to the drafters. ${ }^{154}$ Opponents of the Fugitive Slave Law had argued that Congress lacked power to legislate outside of the grants of legislative power in Article I, and therefore it could not protect rights based on other provisions of the Constitution. ${ }^{155}$ As Professor Aynes has demonstrated, Representative John Bingham shared the antislavery view that Congress lacked power to enforce provisions of the Constitution where there was no express grant of power. ${ }^{156}$ The privileges and immunities clause of Article IV was such a provision, and a number of the supporters of the Fourteenth Amendment strongly supported empowering Congress to enforce it. ${ }^{157}$ Section 5 was also useful to support enforcement of the other clauses of the Fourteenth Amendment and to ensure constitutional power existed to enact the provisions of the Civil Rights Act of $1866 .{ }^{158}$ Even if Section I had no effect on the scope or content of existing privileges, it operated in tandem with Section 5 to grant Congress express power to enforce them. Thus, a clear grant of congressional power to enforce existing constitutional rights was neither a bad nor a useless thing. ${ }^{159}$

I53. See Erwin Chemerinsky, Constitutional Law: Principles and Policies 476 (2d ed. 2002); Tribe, American Constitutional Law, supra note 9, at I303; Charles L. Black, Jr., A New BirTh OF Freedom: Human Rights, Named and Unnamed 76 (1997); Legislative Reference Service, Library of Congress, The Constrturion of the United States of America, S. Doc. No. 82-170, at 965 (Edward S. Corwin eds., i953); 2 William Winslow Crosskey, Poltrics and the Constitution in the History of THE UNITED STATES I I 9 (I953).

154. See supra notes 27,28, I 53 .

155. See Earl M. Maltz, Fourteenth Amendment Concepts in the Antebellum Era, 32 AM. J. LEGAL Hist. 305, 342 ( 1988 ).

156. Richard L. Aynes, On Misreading John Bingham and the Fourteenth Amendment, IO3 YALE L. J. 57, 74-78 (1993).

157. See supra note 27.

158. Bingham had opposed the Civil Rights Act of 1866 on the grounds that it was unconstitutionaI. Cong. Globe, 39th Cong., Ist Sess. I 290-93 (1866). One of his reasons for proposing the Fourteenth Amendment was to assure federaI power to enact such a Iaw, and many other supporters of the Amendment commented that it would constitutionalize the Civil Rights Act of I866. Id. at 1290-96. It was never necessary to consider the idea of a retroactive constitutionalization because the Civil Rights Act of May 31, I870, ch. I I4, I6 Stat. 140, expressly reenacted the Civil Rights Act of I866, though section 16 of the act extended the rights in Section I of that act to "all persons within the jurisdiction of the United States." Civil Rights Act, ch. I I4, I6 Stat. I40 (1870).

159. Decades earlier, Chief Justice Marshall had argued that a constitutional provision might simply make an implied power an express one when he discussed the meaning of "necessary" in McCulloch v. Maryland,: "If no other motive for its insertion can be suggested, a sufficient one is 
Critics point out that the Court had already upheld congressional power to enforce the Fugitive Slave Act in Prigg v. Pennsylvania, ${ }^{160}$ despite the views of the antislavery activists, so there was no need for Section 5 to assure Congressional power to enforce the Amendment. ${ }^{161}$ However, Prigg left open whether Congress could exercise control over state officers and agencies to make them follow constitutional mandates. Kentucky v. Denison, ${ }^{162}$ in which Justice Taney refused to order the Governor of Ohio to deliver a fugitive, could be used to argue that it could not. ${ }^{163}$ Thus, Section 5 was quite useful to make it clear that Congress could enact legislation directed against the states. Indeed, the Court has found that laws passed pursuant to Section 5 can confer a private right of action against the state that trumps state sovereign immunity, at least when enforcing the equal protection clause of that Amendment. ${ }^{16_{4}}$

Professor William Rich has argued that congressional power to create private actions against the state when it is enforcing the privileges and immunities clause goes even farther than the Court has yet recognized. ${ }^{165}$ Justice Miller stated that privileges or immunities include those that "owe their existence to the Federal government, its National character, its Constitution or its laws." ${ }^{166}$ Rich argues that, when Miller mentioned the "right to use navigable waters," Miller was referring to congressional power under the commerce clause and more generally congressional power under Article I, Section $8 .^{167}$ Thus, Rich argues that rights derived from the statutes of the United States are privileges or immunities of citizens of the United States. ${ }^{168}$

Professor Rich notes that, for purposes of analyzing congressional power to create personal rights to sue a state for violating a federal statute, the Court distinguishes between those laws based on federal power

found in the desire to remove all doubts respecting the right to legislate on that vast mass of incidental powers which must be involved in the constitution, if that instrument be not a splendid bauble." I 7

U.S. (4 Wheat.) 316, 420-21 (1819).

I60. 4 I U.S. (I6 Pet.) 539,623 (I842).

16I. 6 FAIRMAN, supra note 77 , at I276.

162. 65 U.S. (24 How.) 66, 90 (1858).

163. See Raoul Berger, Government by Judiciary: The Transformation of the Fourteenth Amendment 250 (2d. ed., Liberty Funds 1997) (1977); Laurent H. Franz, Congressional Power to Enforce the Fourteenth Amendment Against Private Acts, 73 Yale L. J. I353, 1357 (1964); Aynes, On Misreading, supra note 156 , at $77-78$.

I64. Fitzpatrick v. Bitzer, 427 U.S. 445 (1976); Bd. of Trs. of Univ. of Ala. v. Garrett, 53I U.S. 356, 364 (200I); Nev. Dep't of Human Res. v. Hibbs, I23 S. Ct. I972, I977 (2003).

165. See, e.g., Rich, Taking "Privileges or Immunities" Seriously, supra note 6 at 230-32.

166. Id. at 174 (citing Slaughter-House Cases, 83 U.S. 36,78 (1872)).

I67. Id. at 182 .

168. See Rich, Taking "Privileges or Immunities" Seriously, supra note 6, at 182 , 195-96; see also David S. Bogen, Privileges and Immunities: A Reference Guide to the United States ConstituTION I23-24 (2003). 
prior to the Fourteenth Amendment and laws passed pursuant to the Fourteenth Amendment's Section 5. ${ }^{169} \mathrm{He}$ argues that a law granting a private remedy against a state for violation of federal law enforces a privilege or immunity of citizens of the United States and therefore the principle of sovereign immunity that applied prior to the Fourteenth Amendment does not apply. ${ }^{170}$ The slew of cases decided this past decade denied Congress power to create private rights of action against states because counsel failed to argue privileges or immunities enforcement $!^{171}$ If Rich is correct, the strongest argument for an incorporationist reading of the Slaughter-House Cases disappears. Even if Section I created no new rights, it would serve the function of providing a basis for federal legislation that overcomes state sovereignty.

The Court's new federalism decisions on state sovereign immunity may be questionable, but Rich does not directly attack them. ${ }^{172}$ There is a substantial argument that the Eleventh Amendment was directed at precluding private actions against a state when jurisdiction was founded on diversity of citizenship rather than federal law. ${ }^{173}$ The Court's extension of a more general notion of sovereign immunity that applies even when diversity does not attach is on shaky ground. ${ }^{174}$ But if the Constitution did not preclude Congress from creating private causes of action against states prior to the Fourteenth Amendment, the congressional power to enforce the privileges or immunities clause as interpreted by the Slaughter-House Cases would not have added much. Thus, Rich does not challenge the premise that state sovereign immunity precluded federal private causes of action for state violations of federal law prior to the Fourteenth Amendment. Instead, he contends that the Fourteenth Amendment worked a sea change, giving the federal government power to override state sovereignty that it never previously possessed. ${ }^{175}$

I69. Rich, Taking "Privileges or Immunities" Seriously, supra note 6, at 208.

170. Id. at 215-16.

I7I. $I d$. at 208.

172. Id.

173. See John J. Gibbons, The Eleventh Amendment and State Sovereign Immunity: A Reinterpretation, 83 Colum. L. Rev. I889, 1927-60 (1983); William A. Fletcher, $A$ Historical Interpretation of the Eleventh Amendment: A Narrow Construction of an Affirmative Grant of Jurisdiction Rather Than a Prohibition Against Jurisdiction, 35 STAN. L. Rev. 1033, 1035-38 (1983).

174. See David L. Shapiro, Comment, Wrong Turns: The Eleventh Amendment and the Pennhurst Case, 98 HaRv. L. Rev. 61, 70 (1984); John E. Nowak, The Scope of Congressional Power to Create Causes of Action Against State Governments and the History of the Eleventh and Fourteenth Amendments, 75 Colum. L. Rev. 1413, 1445-53 (1975); Lawrence H. Tribe, Intergovernmental Immunities in Litigation, Taxation, and Regulation: Separation of Powers Issues in Controversies About Federalism, 89 HARV. L. Rev. 682, 683-88 (1976).

175. See generally Rich, Taking "Privileges or Immunities" Seriously, supra note 6. 
Unfortunately, the argument to give a new function to the status quo reading of the privileges or immunities clause has both a technical weakness and a political gap. Politically, it seems inconceivable that the Court would abandon its new federalism views of state sovereign immunity simply because counsel argues with a new clause. ${ }^{176}$ The new argument does not reduce the friction created by permitting private citizens to control litigation against the state fisc. The Court is likely to accept it only if its logic is inescapable. But, alas, the logic is not.

Congressional power to overcome state sovereign immunity is a bootstrap construction. If the power to enact the underlying substantive federal law comes from grants in the original Constitution, the "privilege of federal law" protected against state abridgment in Section I is limited by the principle of state sovereignty and does not include a private cause of action. ${ }^{177}$ Even though Congress can pass whatever law is "necessary and proper" to carry into execution the powers stated in Article I, Section 8 , it cannot confer a private action against the state. ${ }^{178}$ Private enforcement of rights is through the Ex parte Young ${ }^{179}$ injunction of state officers on the theory that the injunction is against a person and not against the state. ${ }^{180}$ If the individual had no rights agamst the state under Section I of the Fourteenth Amendment, the "privilege" would not run against the state. The Section 5 power to enforce the privilege may be limited to enforcing the federal law and not extended to the creation of a new right. Other portions of the Fourteenth Amendment (the equal protection and due process clauses) create rights in the individual against the state. Even some privileges or immunities of United States citizenship (like the right to travel) are rights of the individual against the state. The framers of the Fourteenth Amendment were emphatic in attempting to make sure that Congress could deal with a state violation of limits imposed directly by the Constitution. Congressional enforcement under Section 5 merely provides the specific procedures for enforcing an existing right against the State. Because a privilege based in the Constitution can easily be distinguished from a privilege recognized by the Constitu-

I76. A different clause may provide an excuse for a decision that reaches a result contrary to prior cases, but only when the Court independently wants to reach that result due to changed circumstances in society and on the court. E.g., Baker v. Carr, 369 U.S. 186, 218-37 (1962) (holding reapportionment justiciable under equal protection challenge despite Luther v. Borden, 48 U.S. (7 How.) I, 39-47 ( 1849 ), finding a challenge to the election process not justiciable under the guarantee of a republican form of government).

I77. Seminole Tribe of Fla. v. Florida, 517 U.S. 44, 72 (1996); Alden v. Maine, 527 U.S. 706, 71 2 (1999).

178. Seminole Tribe of Fla., 517 U.S. at $72 ;$ Alden, 527 U.S. at 712.

179. 209 U.S. 123 (1908).

I80. See id. This theory has facilitated federal control of state behavior without directly challenging the state purse. 
tion that is based on statute, the Court can readily limit Section 5 power to the former.

In the hands of a sympathetic court, Rich's ingenious argument might suggest a way around the precedents. Ex parte Young is a bit of a fiction anyway. Perhaps a court may one day be sympathetic-although if the court were sympathetic to ending state immunity it would be more likely to simply overrule the earlier cases. For the near future, the Court won't want to abandon the line of cases it has just decided-and the bootstrap logic of Section 5 enforcement will not force it to surrender.

As long as the Court adheres to precedent, the privileges or immunities clause refers only to rights whose source lies elsewhere. Section 5 of the Fourteenth Amendment makes explicit that Congress has power to enforce the rights in Section I, but the Court would probably have found that power implicit in the document anyway. Thus, the privileges or immunities clause serves no creative function in the document. The sterility of this interpretation makes the Slaughter-House Cases a tempting target.

\section{Slaughter-House Three: Revisionist Arguments That the SLAUGHTER-House CASES SUPPort INCORPORATION OF THE}

\section{BILL OF RigHTS}

While there have always been individuals who read Justice Miller's opinion to support incorporation, ${ }^{181}$ the position has attracted its greatest support in recent years. Professor Robert Palmer argued that the language of the opinion supports incorporation, and that the idea was repudiated only later in Cruikshank. ${ }^{182}$ Kevin Newsom argued that incorporation was consistent with Miller's philosophy and with his position in subsequent cases. ${ }^{183}$ Finally, Professor Bryan Wildenthal built on Newsom and Palmer, using the views of democratic congressmen immediately after the decision to support the incorporationist reading. ${ }^{184}$

\section{A. The Language of the Opinion}

Professor Robert Palmer claimed Justice Miller intended to support the incorporation of the Bill of Rights, based primarily on the language of Miller's opinion. ${ }^{185}$ The linguistic argument alone, however, is inconclusive, and suffers from the necessity of treating the right simultane-

181. Professor Mark deWolfe Howe pointed out the potential for an incorporation reading of Miller's opinion in the Constitutional Law class I attended forty years ago. John Hart Ely suggested it as well in Democracy and Distrust 196 n.59 (Harvard University Press I980) (1938).

182. See Palmer, supra note 8 , at 762-70.

183. Newsom, supra note 8, at 706-1 2.

184. See Wildenthal, supra note 8, at 1 I 16-34.

185. Palmer, supra note 8 , at 739-56. 
ously as concrete and abstract. The real crux of the argument is that Miller must have intended the clause in the Constitution to have an effect, and incorporation is the only interpretation that would change the law without implicating fundamental rights reasoning. However, whether Miller intended the clause to have an impact or to be redundant is the basic question.

Palmer contended that Miller's list of privileges and immunities of national citizenship responded to the claim that his opinion had nullified the privileges or immunities clause. ${ }^{186}$ The supremacy clause of Article VI already precluded states from abridging any privilege of federal citizenship. ${ }^{187}$ Palmer argued that Miller needed to interpret the clause to incorporate the Bill of Rights to give it meaning. However, Miller's mention of numerous rights (interstate travel, protection abroad, commerce and navigation, treaty rights, and rights under the Civil War amendments) unaffected by an express prohibition on state abridgment undermmes the argument that his list's purpose was to show that Section I of the amendment changed the status quo.

Miller wrote in the Slaughter-House Cases headnotes that the clause placed privileges and immunities under congressional protection, and he indicated in Bradwell v. Illinois ${ }^{188}$ that the Fourteenth Amendment transferred powers to the Federal government when he said that the right to regulate the license to practice law was "one of those powers which are not transferred for its protection to the Federal government." ${ }^{\text {"189 }}$ Palmer relied on these comments to argue that Miller supported incorporation. ${ }^{190}$

186. Id. at 748 .

187. For example, Miller said the protection of the federal government while in foreign lands was a privilege of citizens of the United States. With no jurisdiction or presence in foreign lands, States could do nothing that would abridge that privilege. Id. Consequently, the inability of the state to interfere with a privilege unless it was directly applicable to the state does not show that Miller intended the rights he mentioned to apply to the states. This undercuts Palmer's contention that Miller must have mentioned habeas as part of a theory of incorporation because the clause would only affect habeas if it applied to habeas issued by state courts. Id. at 749-50. Further, the state could interfere with habeas either by blocking access to federal courts or by refusing to honor habeas for prisoners in state custody. Congress had extended the federal writ in 1867 to apply broadly to persons in state custody. Judiciary Act, ch. 28, \& 1, 14 Stat. 385-86 (1867). The writ had previously been extended to some particular situations of state imprisonment that threatened federal interests, but the new constitutional protections of the Thirteenth and Fourteenth Amendment made federal processes for enforcement of constitutional rights in states even more critical. See Jordan Steiker, Incorporating the Suspension Clause: Is There a Constitutional Right to Federal Habeas Corpus for State Prisoners?, 92 Mich. L. Rev. 862,868 (1994). This statutory extension of the constitutional guarantee did not need the doctrine of incorporation to be binding on the states. As a federal right, the writ was a privilege of national citizenship. Rejection of the writ by a state court would therefore abridge a privilege of citizens of the United States.

188. 83 U.S. (16 Wall.) I 30 (1872).

I89. Bradwell, 83 U.S. (I6 Wall.) at $\mathrm{I} 39$. Palmer, supra note 8 , at 752.

190. Palmer, supra note 8, at 752-53. 
But Miller's statements are wholly consistent with the declaratory status quo interpretation. The Amendment made explicit what had only been implicit: It located the privileges and immunities within Congressional power to enforce. It was Section 5, not the privileges in Section I that was new. Further, the Fourteenth Amendment gave the federal government power to enforce due process and equal protection. Both were transferred from being wholly matters of state law into a matter of federal concern. Miller's Bradwell remark could refer to those rights; thus, it does not suggest that he thought the Bill of Rights was incorporated ${ }^{191}$ In short, there is no affirmative statement from Justice Miller that federal powers were expanded by the privileges and immunities clause in Section I of the Fourteenth Amendment, and nothing remotely resembling express support for incorporation.

Palmer's argument amounts to asserting the incorporation reading and insisting that Miller meant to give the privileges and immunities clause independent content beyond making express what was already implicit. ${ }^{192}$ That assumption is the crux of his argument, and it assumes what the argument is supposed to prove.

Justice Miller did not say that he was describing the privileges or immunities of citizens of the United States in order to show that the amendment effectuated a change. ${ }^{193} \mathrm{He}$ did not say that the clause created new privileges or gave them any new operation. ${ }^{194} \mathrm{He}$ was insistent that the privileges or immunities clause did not apply to fundamental rights, which was the only mode of interpretation that had previously been understood to work incorporation. ${ }^{195}$ Most of the privileges he mentioned could not have been affected by the clause. Their listing makes sense only if its purpose was to demonstrate that the category of privileges and immunities of citizens of the United States is not an empty one. Miller said that was exactly what he was doing: "lest it should be said that no such privileges and immunities are to be found if those we have been considering are excluded."196

Miller repudiated the idea that the fundamental rights of citizens were privileges or immunities of citizens of the United States except for "the very few express limitations which the Federal Constitution im-

19I. Further, saying that one power was not transferred for its protection to the federal government does not assert that other powers have been transferred. It is somewhat strange, in any event, to consider restrictions on government as "powers."

192. See Palmer, supra note 8.

193. See Slaughter-House Cases, 83 U.S. (16 Wall.) 36 (1872).

194. See id.

195. See, e.g., id. at 60.

I96. Id. at 79 . 
posed upon the [s]tates"197 before the Amendment was adopted. The incorporation interpretation of his opinion asserts that he believed limitations on the federal government that were never expressly imposed on the states were "privileges or immunities of citizens of the United States" as abstract general rights, not just as the concrete right specified in the document. But the tenor of the opinion seems opposed to a definition of privileges of citizens of the United States that includes abstract general principles applicable to any government. He referred to privileges "which owe their existence" to the Constitution, but the right to assembly was a preexisting natural right. The Constitution only created a privilege against federal interference with that right.

Although the Fourteenth Amendment expressly prohibits states from denying due process or equal protection, rights that did not previously apply against the states, that does not mean that the amendment altered the meaning or effect of privileges or immunities of citizens of the United States, rights that always applied against the states. Miller's language cautions against interpreting his opinion to produce radical change:

[W] do not see in those amendments any purpose to destroy the main features of the general system. Under the pressure of all the excited feeling growing out of the war, our statesmen have still believed that the existence of the States with powers for domestic and local government, including the regulation of civil rights the rights of person and of property was essential to the perfect working of our complex form of government, though they have thought proper to impose additional limitations on the States, and to confer additional power on that of the Nation. ${ }^{198}$

Palmer pointed out the potential to interpret Miller's opinion to support incorporation, but his argument that it was Miller's intent rested on an unproved assumption. It did little to undermine the conventional wisdom that Miller's failure to expressly adopt imcorporation, and his acquiescence in later decisions denying incorporation, showed that he meant in Slaughter-House that the privileges and immunities clause was a declaration of the status quo.

\section{B. Justice Miller's Philosophy}

Kevin Newsom took the incorporationist reading two steps beyond Palner in an article in the Yale Law Journal. He argued that incorporation was the proper reading of the ambiguous language in the opinion because it was consistent with Miller's basic philosophy and, more impor- 
tantly, with his pattern of votes in other Reconstruction era cases. ${ }^{199}$ Like Palmer, Newsom read the ambiguity in the opinion as more likely to imply incorporation. ${ }^{200}$ His article then was primarily an attempt to support the incorporationist reading by showing that it is plausible in context.

Newsom said that the key elements of Miller's philosophy were "(I) respect for the federal-state balance, (2) deference to original intent, (3) concern for the overburdening of the federal courts, and (4) disdain for laissez-faire constitutional theory." ${ }^{201}$ Except for original intent, these elements of Miller's philosophy not only supported his rejection of fundamental rights, but they supported a rejection of incorporation. The conventional view that Miller's opinion denuded the privileges and immunities clause of any independent force would have preserved the preexisting federal-state balance, taken the courts out of the business of striking laws down, restrained growth in federal litigation, and avoided laissez-faire constitutionalism. Incorporation shifts the balance further toward the federal government, leads to invalidations of law by the court, and interposes the court in more litigation. Thus, the philosophical argument largely cuts against incorporation. The only conflict that Newsom identified between Justice Miller's philosophy and the status quo reading of his opinion was his respect for the original intent of the framers ${ }^{202} \mathrm{But}$ Miller's repudiation of fundamental rights meaning was just as contrary to original intent as any view on incorporation.

There is no contemporaneous historical support whatsoever for the proposition that the privileges and immunities clause was intended to apply only to rights expressly protected against the federal governınent in the original Constitution and not to any other rights deemed fundamental. Representative Bingham and Senator Howard were the only members of Congress who explicitly said that the Bill of Rights was made applicable to the states by the Fourteenth Amendment during the debates on the amendment. Howard's statement of the meaning of privileges or imınunities when presenting the clause to the Senate included the fundamental rights recital of Bushrod Washington in Corfield $v$. Coryell, which Miller expressly excluded from the definition of privileges of national citizenship. ${ }^{203}$

Representative Bingham's references to the Bill of Rights during the debates were ambiguous because he believed that the privileges and immunities of Article IV included all the rights in the first eight Amend-

199. Newsom, supra note 8 , at 687 .

200. Id. at 649 .

20I. Id. at 707

202. Id. at 696-703.

203. Cong. Globe, 39th Cong., ist Sess. 2765 (1866) (statement of Sen. Howard). 
ments. ${ }^{204} \mathrm{He}$ seemed to distinguish between a generalized bill of rightsthe "privileges and immunities" of Article IV-and the specific Bill of Rights of the original articles of amendment. Thus, he spoke of "the provisions in the bill of rights, that the citizens of the United States shall be entitled to all the privileges and immunities of citizens of the United States in the several States, and that no person shall be deprived of life, liberty, or property without the due process of law," and "the bill of rights that all shall be protected alike in life, liberty, and property." ${ }^{205} \mathrm{He}$ was clear that his proposed amendment gave the federal government power to enforce "the bill of rights under the articles of amendment to the Constitution, ${ }^{2006}$ because he understood the privileges and immunities in Article IV mcluded all the rights important in the relationship of a citizen to the state, including equal protection.

Bingham's most explicit statements about the incorporation of the Bill of Rights came with reference to an earlier form of the amendment, a form that tracked the language of Article IV and spoke of the "privileges and immunities of citizens in the several states" rather than the later language of "privileges or immunities of citizens of the United States." ${ }^{207}$ However, Justice Miller im the Slaughter-House Cases ${ }^{208}$ seized on the difference between the privileges specified in Article IV and the new language of privileges of citizens "of the United States" in the Fourteenth Amendment to distinguish the two concepts. ${ }^{209}$

After the current language of the Fourteenth Amendment was introduced, no one during the debate in the House of Representatives on its adoption made a clear statement that it incorporated any of the Bill of Rights against the states, although Bingham came close when he said that imposition of cruel and unusual punishment by a state "contrary to the express letter of your Constitution" was a problem that the amendment would remedy. ${ }^{210}$ But Bingham's cruel and unusual example was punish-

204. Cong. Globe, 39th Cong., ist Sess. 1089 (I866) (statement of Rep. Bingham).

205. Id. at $1094-95$.

206. Id. at 1089 .

207. Id.

208. 83 U.S. ( 16 Wall.) 36 ( 1872 ).

209. See id. at 75 .

210. Cong. Globe, 39th Cong., Ist Sess. 2542 (I866) (statement of Rep. Bingham). Four years after the amendment, Bingham said that he changed the form of the amendment from his first proposal to make it clear that it incorporated the Bill of Rights. "Is it not clear that other and different privileges and immunities than those to which a citizen of a state was entitled are secured by the provision of the fourteenth article, that no state shall abridge the privileges and immunities of citizens of the United States, which are defined in the eight articles of amendment." Cong. Globe, 42nd Cong., Ist Sess. 84 (1871) (statement of Rep. Bingham). But he did not articulate this distinction between the privileges of citizens of a state and of the United States durmg the adoption debates, and instead referred sweepingly throughout to the privileges in the Fourteenth Amendment as based on the privi- 
ment by confederate states for refusing to renounce allegiance to the Union. He went on to say that "the right to bear true allegiance to the Constitution and laws of the United States, and to be protected in life, liberty and property" ${ }^{\text {"2II }}$ were Article IV privileges of citizens that needed protection by the explicit grant of power to Congress that was in the Fourteenth Amendment. ${ }^{212}$ Virtually everyone else who spoke on the privileges and immunities clause also identified them with the fundamental rights of Article IV. ${ }^{213}$ Yet Miller very specifically repudiated any understanding that the privileges of Article IV were the same as the privileges in the Fourteenth Amendment.

Newsom pointed to a trip Justice Miller took with Representative Bingham prior to the decision as further support for reading the case as incorporating ${ }^{214}$ but this seems to be guilt by close association. The basis for any sound historical argument that the privileges and immunities clause incorporated the Bill of Rights is that they were fundamental rights of citizenship like the rights to contract and property. ${ }^{215}$ Justice Miller repudiated the fundamental rights reading of the clause. Thus, his supposed fidelity to original intent did not prevent him from ignoring these statements of the framers.

There were, however, some statements by participants in the adoption process that lent support to rejecting incorporation. Maryland Senator Reverdy Johnson famously objected to the privileges and immunities clause: "I do not understand what will be the effect of that."216 Miller would also be aware of Senator Lyman Trumbull's statement in the debates over a civil rights statute in I87I that the Fourteenth Amendment merely repeated the language of Article IV and added nothing to it:

The protection which the Government affords to American citizens under the Constitution as it was originally formed is precisely the protection it affords to American citizens under the Constitution as it now exists. The fourteenth amendment has not extended the rights and privileges of citizenship one iota.... National citizenship is one thing, and State citizenship another; and before this constitutional amendment was adopted the same obligation, in my judgment, rested upon the Government of the United States to protect citizens of the United States as now. ${ }^{217}$

leges in Article IV. Cong. GloBe, 39th Cong., Ist Sess. I089, I094-95, 2542 (I866) (statement of Rep. Bingham).

2II. Cong. Globe, 39th Cong., Ist Sess. 2542 (I 866) (statement of Rep. Bingham).

212. Id.

213. Supra note 28.

2I4. Newsom, supra note 8 , at 700 .

215. See supra text accompanying notes $25-32$.

2I6. Cong. Globe, 39th Cong., Ist Sess. 304I (I866) (statement of Sen. Johnson).

217. Cong. Globe, 42nd Cong., ist Sess. 576-77 (1871) (statement of Sen. Trumbull). 
Thus, Miller's philosophy of original intent would not preclude him from taking the view that Bingham first articulated: the privileges and immunities clause would only enable Congress to enact laws to enforce those rights which already existed against the states. The difference was that Justice Miller understood full well, contrary to the position of Bingham and others in Congress, that there was no previous right against any state to any of the protections of the Bill of Rights. The Amendment was built on a faulty premise, and honoring the intent of the framers did not require Miller to ignore what they said.

\section{Justice Miller's Votes in Subsequent Cases}

Newsom claimed that Miller's position in subsequent cases was consistent with a belief in incorporation of the Bill of Rights. ${ }^{218}$ This is significant because Miller's acquiescence in the Court's repudiation of incorporation is a major reason for believing that he abjured imcorporation in Slaughter-House. ${ }^{219}$. Newsom argued that no subsequent case forced Miller or the Court during Miller's tenure to discuss specifically whether the first eight Amendments were incorporated. ${ }^{220}$ Either the discussion on mcorporation was dicta, counsel failed to rely on the Fourteenth Amendment as incorporating earlier guarantees, or counsel sought to use another clause of that amendment. Cruikshank involved a failure to allege the state action necessary to find a violation of the Amendment ${ }^{221}$; counsel attempted to apply the Bill of Rights directly without referring to the Fourteenth Amendment in Twitchell, ${ }^{222}$ and the rejection of incorporation in the Hurtado ${ }^{223}$ case was based entirely on the due process clause. ${ }^{224}$

Newsom was technically correct that the Court did not have to face an issue of privileges and immunities incorporation in any of these decisions, though it is hard to shake the impression that the tenor of the decisions opposed it. For example, Presser, ${ }^{225}$ which Newsom does not mention, stated that the Second Amendment does not apply to the states without mentioning any Fourteenth Amendment argument. ${ }^{226}$ But Justice

218. Newsom, supra note 8, at 706-33.

219. See generally Aynes, supra note 68, at 653-55.

220. Newsom, supra note 8 , at 706-33.

221. 92 U.S. 542,549 (1876).

222. Twitchell v. Pennsylvania, 74 U.S. (7 Wall.) 321, 324-27 (1869). The same was true in Eilenbecker v. Dist. Ct. of Plymouth County, I34 U.S. 3 I (I890), a decision that Miller hinuself wrote. There he rejected clainus under the Fifth, Sixth and Eighth Amendments on the grounds that those amendments applied only to the federal government. $I d$.

223. Hurtado v. California, i 10 U.S. 516 (1884).

224. Newson, supra note 8 , at 7 I 2-26.

225. Presser v. Illinois, 16 U.S. 252 ( 1886 ).

226. Id. at 265 . 
Woods cited the passage from Cruikshank that asserts the right was not created by the amendment but only protected from interference by Congress. ${ }^{227}$ Justice Woods then examined the Fourteenth Amendment privileges and immunities clause to determine whether it was violated, but he did not back reference the right to bear arms. ${ }^{228}$ Technically, this much of the opinion was consistent with not directly facing the incorporation issue, but it is hard to believe that its author believed that the privileges and immunities clause made the Second Amendment applicable to the states.

Justice Woods said the First Amendment right to petition and assemble was the only clause in the Constitution that could have any relationship to associating with others. According to Woods, Cruikshank said the right was one of national citizenship, but the right to assemble was not protected by the clause unless the assembly was for national purposes. ${ }^{229}$ That mis-described Cruikshank, which did not interpret the right of assembly so narrowly, and found the privilege of assembling to discuss national issues arose from the nature of the national government rather than from the First Amendment clause.$^{230}$ But Woods understood it was the national purposes, not the First Amendment, that made the assembly a privilege of national citizenship:

It cannot be successfully questioned that the State governments, unless restrained by their own Constitutions, have the power to regulate or prohibit associations and meetings of the people, except in the case of peaceable assemblies to perform the duties or exercise the privileges of citizens of the United States. ${ }^{231}$

The civil jury decisions pose the greatest problem for Newsom's argument, because the Court expressly stated that the civil jury in state court was not a Fourteenth Amendment privilege or immunity. Edwards $^{232}$ was dicta, but Newsom conceded that Miller seemed to join other members of the court in saying that the right to a jury in civil cases was not applicable to the states. ${ }^{233}$ Newsom argued that the original un-

227. Id. at $266-67$.

228. $I d$. at $265-66$.

229. Id. at $264-66$.

23o. See United States v. Cruikshank, 92 U.S. 542 ( 1876 ). Newsom points out that Woods had supported incorporation in his opinion as a federal circuit judge in United States v. Hall, 26 F. Cas. 79, 82 (S.D. Ala. I87I). Newsom, supra note 8, at 726. Woods and Bradley issued an early opinion in the Slaughter-House Case on circuit giving a fundamental rights reading to the privileges and immunities clause. Newsom's suggestion that Woods supported incorporation after his elevation to the Supreme Court, however, seems to fly in the face of Woods' treatment of the Second Amendment in Presser and his vote in Hurtado against incorporation through the due process clause.

23I. Presser, I16 U.S. at 267.

232. Edwards v. Elliott, 88 U.S. (21 Wall.) 532 (I874).

233. Newsom, supra note 8 , at 728 . 
derstanding of the Fourteenth Ainendment did not include the right to a civil jury trial-it concerned federalisin rather than individual rights since it protected the jury in diversity cases, it was not listed by Senator Howard, and several states that ratified the amendment had provisions inconsistent with its incorporation. ${ }^{234}$ Even Justice Bradley concurred in both Edwards ${ }^{235}$ and Walker v. Sauvinet. ${ }^{236}$ Newsoin distinguished Miller's joining Waite's opinion in Walker, which expressly states that civil trial by jury is not a privilege or immunity of federal citizenship, as a sui generis inatter because of Miller's aversion to the jury. ${ }^{237}$

Newsom's case analysis precludes reading Miller as applying every provision of the Bill of Rights to the states. Thus, even Newsom ultimately denies the total incorporation theory. ${ }^{23^{8}}$ In the final analysis, Newsom offered a good case to show that the decisions of the court on the privileges and immunities clause were poorly considered and, other than with respect to the civil jury, the holdings did not technically deny incorporation. But all his originality and skill fail to make a persuasive case that Miller supported incorporation-rejection is more consistent with Miller's votes in subsequent cases and everything else he said. ${ }^{239}$

234. Newsom, supra note 8 , at 729-30. Newsom cites Amar for the federalism point. Id. at 729 n.4 8 (citing Akhil Reed Amar, The Bill of Rights: Creation and Reconstruction 89 (1998)). Professor Stanton Knauss has criticized Amar's federalism argument, but his suggestion might also be used to distinguish jury trial from other amendments for incorporation purposes. Knauss contended that the jury trial amendment essentially delegated power to Congress to determine which cases should be tried by a jury - a delegation notion that would not be readily transferred to the state level. See Stanton D. Knauss, The Original Understanding of the Seventh Amendment Right to Jury Trial, 33 U. RICH. L. Rev. 407 (1999).

235. 88 U.S. (2I Wall.) 532 ( 1874$)$.

236. 92 U.S. 90 (1875).

237. Newsom, supra note 8 , at $730-32$.

238. Bryan Wildenthal analyzed Newsom's discussion of the cases in some detail. Although Wildenthal agreed with Newsom's incorporationist view of Slaughter-House, he disagreed with Newsom's interpretation of the later cases. Wildenthal, supra note 8, at 1065-66. Wildenthal said that the civil jury was not "uniquely unsusceptible to mcorporation." Id. at II47 (see discussion at I144-46). He observed that the decisions between 1874 and 1876 backed away from incorporation. He examined Edwards and Walker, noting the defects in argument but disagreeing with Newsom on their significance. He then did the same with Cruikshank, pointing out that counsel did not make incorporation an issue in that case and in fact favored it. Nevertheless, his analysis of Waite's opinion showed Newsom's missteps and the clear anti-incorporationist structure of the opinion. Id. at I I48-61. He concluded that incorporation had lost before the 1877 Compromise, but by inattention and neglect rather than as a fully debated concept. Id. at II61-69.

239. Professor Aynes also notes that Justice Miller's I 880 lectures did not give a hint of an incorporation reading of either the Slaughter-House Cases or the privileges or immunities clause, and indeed seemed to reject incorporation specifically with respect to the First Amendment's establishment clause. Aynes, supra note 68 , at 655 . Miller said the federal government had "no right to raise money by taxation for religious purposes, or for a thousand things on account of which States may impose taxes and collect them of people." Samuel Freeman Miller, Lectures on the Constrtution of the UNITED STATES I04 (New York, Banks and Brothers I893). 


\section{The Congressional Democrats' Reaction}

Like Newsom and Palmer, Professor Bryan Wildenthal contended that Miller's language makes more sense as supporting incorporation. Much of his article and its sequel were designed to show that incorporation was the proper interpretation of the Fourteenth Amendment and that contemporaries understood that to be true and continued to battle for incorporation, despite the opinions of the majority. ${ }^{240}$ Wildenthal's contentions with respect to Slaughter-House focused on the opinions in the case ${ }^{241}$ and its reception in Congress, ${ }^{242}$ where members of the Democratic minority interpreted the opinion to support incorporation.

The Slaughter-House opinion frustrated congressional Republicans, because of its effect on the debate over a proposed bill to prohibit discrimmation in public accommodations. Democratic representative James Beck of Kentucky quickly asserted that the Slaughter-House Cases decision denied Congress power over the subject. ${ }^{243}$ Discussion of the case focused on its impact on the bill and forced the bill's supporters to shift their rationale to the equal protection clause and to debate state action concerns.

Some congressmen, of course, did not understand the case. Congressman John T. Harris of Virginia said that the majority and the minority concurred in the definition of privileges and immunities of a citizen of the United States "that they mean 'the fundamental rights of life, liberty, and property." "244 But most members understood that the SlaughterHouse Cases repudiated a fundamental rights view and that a constitutional basis for the new Civil Rights Act would have to be found elsewhere. ${ }^{245}$ Whether Miller intended incorporation of the Bill of Rights was irrelevant, because the proposed legislation did not deal with any of those rights.

Nevertheless, some Democratic opponents of the bill asserted an incorporationist reading of the privileges and immunities clause after Slaughter-House. Thus, not only was the language capable of being read as supporting incorporation, but several contemporary politicians read it that way. They at least saw the ambiguity in Miller's opinion and used it

240. Wildenthal, supra note 8; Wildenthal, The Road to Twining: Reassessing the Disincorporation of the Bill of Rights, 6I OHIo ST. L.J. 1457 (2000).

24I. Other than the statements of democratic representatives, Wildenthal's arguments for an incorporationist reading of the majority opinion have already been discussed. See supra note 39 discussing his argument on the views of counsel, and notes 99 and 108 pointing to weaknesses in the analysis of the dissents.

242. Wildenthal, supra note 8, at I I I6-25.

243. Cong. Globe, 43 d Cong., Ist Sess. 342 (1873) (Statement of Sen. Beck).

244. Cong. Globe, 43d Cong., Ist Sess. 376 (I874) (Statement of Rep. Harris).

245. See infra Part I.A. 
to press their argument that the rights in the bill were not protected. Congressman Beck referred to the Bill of Rights as privileges and immunities from Slaughter-House. ${ }^{24^{6}}$ Representative Roger Mills of Texas distinguished rights granted by the state, such as property and jury service, from fixed rights of citizens of the United States, which he said were fundamental. Thus, he said that the privileges are those recognized and guaranteed in the Constitution-i.e., the Bill of Rights. ${ }^{247}$ Congressman William Herndon of Tennessee also referred to the privileges or immunities clause as including rights of free speech and jury trial. ${ }^{248}$ Finally, Senator Thomas Norwood of Georgia said that the Fourteenth Amendment did not grant any new privileges, but it made the guarantees of the Bill of Rights applicable to the states. ${ }^{249}$ Wildenthal points out that the incorporationist views of the Slaughter-House Cases voiced in Congress were not contradicted, and he suggests they are "entitled to substantial weight in any assessment of the contemporary understanding of Slaughter-House." $" 250$

These congressional remarks are not convincing evidence of the meaning of the majority opinion in Slaughter-House. The only members of Congress who expressly took the incorporation reading were southern Democrats opposed to the proposed civil rights laws. And even they showed some confusion. For example, Representative Mills said "these privileges are, among others, the right to the enjoyment of life, liberty, property, and the pursuit of happiness," before he continued with the specifications from the amendments. ${ }^{251}$ Republicans neither expressly repudiated nor supported the incorporationist interpretation of the clause after the Slaughter-House Cases. They were more concerned with complaining about the decision or stressing its racial focus for equal protection.

Incorporation theory had two advantages for Democratic congressmen opposed to the Civil Rights proposals. It gave a substantive meaning to the Fourteenth Amendment that might protect white men resisting Reconstruction legislatures, and it denied any support from the clause for federal measures relevant to protecting against racial discrimination. Thus, the Democrats' interpretation of Miller's opinion was politically

246. Cong. Globe, 43 d Cong., ist Sess. 342 (1873) (statement of Rep. Mills).

247. Cong. Globe, 43d Cong., Ist Sess. 384-85 (1874) (statement of Rep. Mills).

248. Cong. Globe, 43 d Cong., Ist Sess. 420 (1874) (statement of Rep. Herndon).

249. Cong. Globe, 43 d Cong., Ist Sess. 242 ( 1874 ).

250. Wildenthal, supra note 8 , at 1125 .

25I. Cong. Globe, 43 d Cong., Ist Sess. $384-85$ (1874) (statement of Rep. Mills). 
desirable as well as linguistically possible. ${ }^{252}$ It was not, however, an accurate perception of the opinion itself.

\section{E. The Failure of Revisionist Theories}

The Slaughter-House revisionists have three legitimate arguments. First, the language of Miller's opinion is open to an incorporationist interpretation, even though it requires apparently inconsistent steps of reasoning to do so. Second, some Democratic members of Congress read the opinion that way. Third, the status quo reading makes the clause redundant.

The purported consistency of the opinion with Miller's philosophy, his votes in other cases, and the statements of the dissenters do not support the revisionist case. Incorporation would have increased the load on federal courts to Miller's dismay. Miller and his colleagues rejected incorporation with fairly clear language within a short period of time. Finally, Slaughter-House dissenters stated that Miller's opinion made the amendment futile, and his failure to respond to them with an explicit statement of incorporation indicates that they were right.

In short, the case of the revisionists depends on heavily discounting the subsequent decisions of the court which Justice Miller joined, or assuming a sudden and otherwise inexplicable about face on a matter of basic principle. Miller's language in Slaughter-House may have been slightly ambiguous, but a declaratory status quo interpretation is the most natural understanding. The incorporation understanding of several Democratic congressmen seems motivated by their desire to limit federal power to protect African Americans while securing protections for themselves against Reconstruction governments. Although the most coherent incorporation theory hinges on believing that the clause embodies fundamental rights, Justice Miller's repudiation of a "fundamental rights" interpretation was the basis for the opinion. Because the opinion itself gave every indication that Miller did not regard the privileges and immunities clause as resulting in any change and the tautology of the status quo analysis did not deter the Court from plainly adopting it within a few years, avoiding a tautological interpretation fulfills the reader's hope for the opinion rather than proving the writer's intent. Even a status quo

252. It seems anomalous that former Supreme Court Justice John Campbell, who joined the Dred Scott majority and resigned from the Court at the outset of the war, was the counsel for the butchers, asserting the broadest view of the Fourteenth Amendment. Professor Rich suggests that Campbell was consistent-advocating private property rights and laissez faire economics whether through states rights or privileges or immunities. Rich, Taking "Privileges or Immunities" Seriously, stupra note 6, at 179. This suggests that while Republicans sought the widest scope for congressional power, Democrats looked to the court as a more reliable protector of their interests. 
reading serves the purpose of erasing any question of congressional power to enforce preexisting rights. Finally, Justice Miller suggested using the Slaughter-House Cases as an appropriate cite for the discussion in Cruikshank that effectively precluded incorporation, and he approved of Waite's opinion in that case. ${ }^{253}$

The conventional wisdom is right: Miller fully intended to repudiate any theory of incorporation when he repudiated a fundamental rights interpretation of the privileges and immunities clause.

\section{Slaughter-House Four: The $S_{\text {laughter-House }}$ Ases SHOUld Be OverRuled}

Justice Miller's critics argue that his repudiation of any form of fundamental rights content for the privileges or immunities clause, includimg incorporation, ignored the history of the amendment and has had terrible consequences for the development of Fourteenth Amendment jurisprudence. Indeed, most commentators on the case today believe that Justice Miller made a mistake and the decision should be overruled. ${ }^{254}$

Justice Miller had a wide variety of choices in interpreting the privileges or immunities clause: he could have adopted Justice Black's mcorporation theory (as the revisionists believe he did); he could have pursued an equality analysis as Professor Nelson suggests Justice Field may have done; ${ }^{255}$ or he might have accepted a natural law view of fundamental rights that would be likely to include the Bill of Rights as Justice Bradley chose. However, each choice had significant drawbacks then and equally serious defects today.

\section{A. The Decision Is Historically Incorrect}

Fourteenth Amendment scholars agree that the framers intended the privileges or immunities clause to be the centerpiece of Section $I^{256}$

253. See FaIrman supra note 136.

254. Aynes, supra note 68, at 628; Thomas B. McAffee, Constitutional Interpretation-The Uses and Limitations of Original Intent, 12 U. DAYTON L. REv. 275, 282-83 (1986); LeONARD W. LEVY, The Fourteenth Amendment and the Bill of Rights, in JUdgments: Essays ON AMERICAN CONSTITUTIONAL History 64, 69 (1972); Louis Lusky, By What Right? A Commentary on the Supreme Court's Power to Revise the Constitution 20I (I975).

255. William E. Nelson, The fourteenth Amendment: From Political Principle to Judicial DOCTRINE I56-58 (I988).

256. See Amar, supra note 234; Berger, supra note i63; Michael Kent Curtis, No State Shall Abridge: The Fourteenth Amendment and the Bill of Rights 12-I3 (I986) [hereinafter Curtis, No State Shall Abridge]; John Denvir, Democracy's Consttution: Claiming the Privileges of American Citizenship 5-6 (200i); Eart M. Maltz, Civil Rights, the Constirution, and Congress, I863-I869, 106 (1990); NELSON, supra note 255; Charles Fairman, Does the Fourteenth Amendment Incorporate the Bill of Rights? The Original Understanding, 2 STAN. L. Rev. 5, 5-139 (1949); John Harrison, Reconstructing the Privileges or Immunities Clause, 101 YALE L. J. I385, 1385-I474 (1992). 
The privileges and immunities clause, rather than due process, was to be the source for substantive restrictions on state government. There seems to be common ground among the critics that Miller was wrong because the historic background of the privileges and immunities clause shows that it should have been given a different substance. At this point, the ground parts and we fall into the abyss of conflicting accounts for the substance of the clause. Scholars disagree greatly about the content of the privileges or immunities clause, particularly with respect to the incorporation of the first eight Amendments of the Constitution to apply to the States. ${ }^{257}$

\section{Privileges and Immunities Incorporated the Bill of Rights}

Michael Curtis has written extensively to show that the framers of the Fourteenth Amendment intended to make the first eight Amendments applicable to the States. ${ }^{258}$ Bingham and Howard said so expressly, and incorporation is at least consistent with the remarks of many others who contended that the privileges or immunities clause secured fundamental rights.

It may be debatable whether every one of the Bill of Rights was to be incorporated against the States. Akhil Amar has suggested that only those involving individual rights and not those concerned with federalism should be applied. ${ }^{259}$ Charles Fairman contended that only those rights fundamental to ordered liberty were included in the "fundamental

257. Michael Curtis and Richard Aynes contend that the privileges of citizens of the United States include all of the Bill of Rights and apply them to the States-total incorporation. See CurTIS, supra note 256; Aynes, supra note 156 at 103-04; Richard L. Aynes, Refined Incorporation and the Fourteenth Amendment, 33 U. Rich. L. Rev. 289, 289-312 (1999) [hereinafter Aynes, Refined Incorporationl. Akhil Amar distinguished individual rights from rights based in federalism, arguing that only amendments creating the former were to be applied against the states. AMAr, supra note 234. Lawrence Tribe and John Denvir have seen the clause as the source for a rich array of unenumerated rights. Tribe, Saenz Sans Prophecy, supra note 9, at II0-98; DENVIR, supra note 256 at 5-IO. At the other extreme, the late Raoul Berger argued vigorously for a limited application of the clause. See BERGER, supra note $\mathrm{I}_{3}$.

258. Michael Kent Curtis, The Bill of Rights as a Limitation on State Authority: A Reply to Professor Berger, I6 WAKe Forest L. Rev. 45 (1980); Michael Kent Curtis, Further Adventures of the Nine Lived Cat: A Response to Mr. Berger on Incorporation of the Bill of Rights, 43 OHг Sт. L.J. 89 (1982) [hereinafter Curtis, Further Adventures of the Nine Lived Cat]; Michael Kent Curtis, The Fourteenth Amendment and the Bill of Rights, I4 ConN. L. Rev. 237 (1982) [hereinafter Curtis, The Fourteenth Amendment and the Bill of Rights]; Curtis, No State Shall Abridge, supra note 228; Michael Kent Curtis, The I859 Crisis Over Hinton Helper's Book, The Impending Crisis: Free Speech, Slavery, and Some Light on The Meaning of the First Section of the Fourteenth Amendment, 68 CHI.-KENT L. REV. I 13 (1993) [hereinafter Curtis, The Impending Crisis]; Curtis, supra note 152; Michael Kent Curtis, Historical Linguistics, Inkblots, and Life After Death: The Privileges or Immunities of Citizens of the United States, 78 N.C. L. REv. 1071 (2000) [hereinafter Curtis, Historical Linguistics, Inkblots, and Life After Death].

259. AMAR, supra note 234 , at $215-30$ 
rights" that other congressmen expected to be identified as privileges or immunities. ${ }^{260}$ But the primary debate is not over whether the framers intended any of the Bill of Rights to apply to the states through the privileges or immunities clause, but how many. The historians' controversy is largely the same as the Court's discussion today - whether total incorporation or selective incorporation-but legal historians would locate the source of incorporation in the privileges or immunities clause rather than the due process clause. Thus, Miller did not follow the framers' intention when he rejected the fundamental rights version of the privileges or immunities clause, which would have resulted in incorporation.

If incorporation was intended, however, it was because the rights stated $\mathrm{m}$ the Constitution were fundainental and not because they were stated in the Constitution. Congress was concerned with the rights that governments were established to protect, such as property and personal safety, although congressmen might have thought the Bill of Rights included because they are equally fundamental to the functioning of free government. Nevertheless, the debates show that privileges or immunities referred to fundainental rights that were universal in nature; it was not simply a synonyın for "those rights explicitly enumerated in the Constitution.,"26

Some form of incorporation is consistent with the statements of the framers. However, limiting privileges and immunities to incorporating the Bill of Rights lacks any historical support, precludes recognition of unenumerated rights, and fastens on the states procedures that would not have been acceptable at the time. It is an ahistorical interpretation that fastens dumb rules on the states and excludes wise ones. Its adoption would be a policy decision on the Court's role: attempting to balance fear of judicial power with concern for vindication of important rights by confining the power to the concrete language found elsewhere in the document.

\section{Privileges and Immunities Require Equality in Rights}

The incorporation of the Bill of Rights, whether totally or selectively, is not the only way to interpret the intention of the framers in drafting the privileges or immunities clause. The phrase "privileges or iminunities" was used in the Fourteenth Amendment because it echoed the existing language in Article IV. As Justice Miller pointed out, Article IV did not create fundamental rights, but simply required a state to grant to citizens of other states those fundamental rights that it granted its

260. Fairman, supra note 256 , at 5-139.

261. See supra notes $17-26$ and accompanying text. 
own. ${ }^{262}$ The citizen of another state was entitled to the same contract and property rights the state afforded its own citizens, but also to the same rights of free speech and jury trial. Fundamental rights in this context mixed affirmative rights to get something from the state (protection of the life, liberty, and property of the individual by traditional contract, property, tort, and criminal law) with negative rights restraining the state.

John Harrison has argued powerfully that the privileges and immunities clause transformed the non-discrimination against out-of-state citizens of Article IV into a prohibition on discrimination by the state against classes of its own citizens. ${ }^{263}$ As Harrison and Professor William Nelson demonstrate, proponents often characterized the Fourteenth Amendment as doing no more than guaranteeing equality. ${ }^{264}$ Fundamental rights described the area where discrimination was forbidden. Before the Fourteenth Amendment was even proposed, Radical Republicans argued in the Civil Rights Act debates that Congress had power to assure all citizens of nondiscrimination in fundamental rights, because such discrimination was a badge or incident of slavery. ${ }^{265}$ Harrison pointed out that the word "abridgment" covers any discrimination that provides fewer affirmative rights for the African American than the white, and thus the clause forbidding any state from abridging the privileges or immunities of citizens of the United States worked to constitutionalize the Civil Rights Act. ${ }^{266}$ Even Justice Field's dissent arguably did not go beyond an equal rights approach to the privileges that he broadly defined; he complained that the slaughterhouse nonopoly was invalid because it unreasonably denied the butchers' rights available to the monopolists and thus denied equality of right in pursuing a trade. ${ }^{267}$

Professor Nelson has suggested that the vision of the amendment as a guarantor of equality reconciles the puzzling inconsistencies that plague attempts to understand the framer's intention with respect to incorporation: Bingham and Howard said the Bill of Rights were privileges and immunities, yet the ratification debates did not discuss incorporation, and state constitutions and laws continued to maintain provisions

262. Slaughter-House Cases, 83 U.S. ( 16 Wall.) 36,77 ( 1872 ).

263. Harrison, supra note 256 , at $1385-474$.

264. Nelson, supra note 255 , at I $15^{-19}$.

265. See supra note 30.

266. Harrison, supra note 256 , at $1420-22$.

267. Nelson, supra note 255 , at $156-58$. Field's "opinion is narrow because it held that not all rights, but only fundamental rights, such as the right to engage in the common occupations, are within the ambit of section one and thus subject to federal judicial control." Id. at 158 . $\mathrm{He}$ "required only that state regulations be reasonable, and he defined a reasonable regulation as one that applies generally and equally to all." Id. 
that were inconsistent with those amendments. ${ }^{268}$ Under an equality interpretation of the amendment, the Bill of Rights were among the fundamental rights that must be extended without discrimination where they were available, but the state was under no obligation to provide them. Congress and the courts could secure the Bill of Rights by insisting that it be extended to the blacks and northerners who had been excluded, but states would be free to decide for themselves that no one would get some particular guarantee. Thus, Nelson argues, Bingham and Howard could refer to the Bill of Rights as privileges and immunities that would now be enforced against the states without threatening to force any state to use grand jury indictment instead of information or impose civil juries where they had not been previously used. ${ }^{269}$

Miller's rejection of Article IV fundamental rights flew in the face of the history and missed the opportunity to assure the equality in fundamental rights that the framers aimed for. On the other hand, limiting the clause to a requirement of equal treatment among citizens with respect to fundamental rights violates the historical understanding that freedom of speech was to be protected against state abridgment, undermines unenumerated rights, and creates interpretative problems for the equal protection clause. Although Harrison attempted to suggest a form of incorporation akm to Amar's, his logic works the other way. Equality resolves the paradox of incorporation in the teeth of contrary state practices by denying incorporation. A doctrine that does not permit any application of the Bill of Rights to the states is as ahistorical as one that is limited to applying all of them.

\section{Privilege and Immunities Include Fundamental Natural Rights}

The language of privileges or immunities in the Fourteenth Amendment was not limited to non-discrimination. As in the First Amendment, "abridgment" goes beyond discrimination to forbid denials of rights. Prohibiting opposition to slavery limits speech in ways the framers would all oppose, yet it does not discriminate against classes of people - only against ideas.

The equahity interpretation of privileges or immunities either is redundant in view of the equal protection clause or it requires that clause to be read narrowly to apply to fewer rights than those that are fundamental, for example only to laws "protecting" existing rights. While many supporters of the new amendment may have envisioned it in antidiscrimination terms, others took a broader view. 
Justice Bradley's fundamental rights interpretation had strong historical support. It incorporated many, and possibly all, of the Bill of Rights as part of the fundamental rights secured against state denial. A number of the Republican supporters of the amendment spoke in absolute rather than equality terms. Indeed, the consistent reference to fundamental rights in the debates point to protection of rights, not merely equality. The absolute rights reading of the privileges and immunities clause has real appeal. It is the only way the clause could effectively protect freedom of speech, which a number of speakers assumed would happen.

But, if fundamental rights include affirmative rights to property and contract as well as negative rights, absolute rights threaten to lead to the unwarranted extension of federal power that Miller feared and the Republican party never openly avowed. That is what drove Justice Miller to the status quo reading of the privileges and immunities clause.

Some Republicans supporting absolute rights offered a theory to argue that the clause did not destroy the role of the states. ${ }^{270}$ Proponents of the Fourteenth Amendment emphasized that the Amendment would have no effect on states that acted justly and did not threaten sovereignty. ${ }^{271}$ They made the Amendment seem like simple justice to which no one could object. ${ }^{272}$ Republicans assumed that states had acted to regulate traditional common law rights, and the federal role would be limited to invalidating the laws that were unreasonable, unfair, or unequal. ${ }^{273}$ Professor Nelson wrote: "[E]ven if fundamental rights were derived from higher law or were the entitlement of citizens independent of state law, those rights could be enjoyed only if state legislatures created rules and mechanisms for their enjoyment." ${ }^{274}$ Thus, states would enact basic laws of contract, property and tort. The Amendment only operated as a check against improper state action, not as an authorization for affirmative contract, property or tort law of the federal government. Property, for example, is an abstract right that exists concretely only in the context of the state regulations that give it form. So long as those regulations were reasonable and equal, the federal government could not affect it.

Trisha Olson has argued, somewhat analogously, that the Amendment embodied a natural law tradition that distinguished universal rights applicable to all persons, which were protected by the due process and

270. Id. at 119-21.

27 I. See Nelson, supra note 255 , at I I4-25.

272. Joseph B. James, The Ratification of the Fourteenth Amendment 44 (ig84).

273. See Nelson, supra note 255 , at I IO-47.

274. Id. at II9. 
equal protection clauses, from privileges and immunities that were based on the particular communities to which the individual belonged. ${ }^{275}$ The natural law analysis regards law as properly declarative of principles rather than creating law, and the subset of privileges or immunities is derived from communities whose relationships are governed by traditional understandings. In a way, Professor Olson's analysis echoes Justice White's selective incorporation decisions, which asked not whether a particular right was fundamental to fairness in any scheme of justice (a universal natural right), but whether it was fundamental in the context of our system. ${ }^{276}$ Thus, privileges even in the natural law tradition are not universal, but peculiar to the history and ethos of the nation. This leaves the state as the proper source for basic laws of property, contract, and procedure.

However, Justice Miller did not see fundamental rights as creating a stable basis for analysis. He feared that if states were forbidden from abridging affirmative obligations to protect the property and security of the individual, the federal power under Section 5 to enforce the command leads inexorably to federal power to (I) determine whether the protections are adequate and (2) to enact adequate laws in traditional state law areas where they are not. ${ }^{277}$ If a state did not have a law of property, how would the federal government enforce the command that the state not abridge the fundamental right of property? If the federal government could enact property laws under Section 5, it would take over the definition of property. As long as privileges and immunities are seen as the fundamental rights that a state owes its citizens, the logic expands federal legislative power beyond the scope the framers intended.

The responses to this point by the dissents in Slaughter-House were not very reassuring. Justice Swayne wrote: "It is objected that the power conferred is novel and large. The answer is that the novelty was known and the measure deliberately adopted. The power is beneficent in its nature, and cannot be abused." ${ }^{278}$ Justice Bradley replied to fears of a federal creation of civil and criminal codes that little action by Congress would be required. But he did not deny that the amendment could be construed to confer such power. "The great question is, What is the true construction of the amendment? When once we find that, we shall find

275. See Trisha Olson, The Natural Law Foundation of the Privileges or Immunities Clause of the Fourteenth Amendment, 48 ARK. L. Rev. 347 (1995).

276. See Duncan v. Louisiana, 39I U.S. I 45 , I 49 n.I 4 (I968).

277. Slaughter-House Cases, 83 U.S. (16 Wall.) 36, 77-78 (1872).

278. Id. at 129 (Swayne, J., dissenting). 
the means of giving it effect. The argument from inconvenience ought not to have a very controlling influence in questions of this sort." ${ }^{, 279}$

The best way to define the federal power to correct wrongs without authorizing wholesale replacement of state power over traditional areas of law is to define rights in terms of restrictions on state government rather than rights to positive acts by the state. Then the limitation goes into effect only upon state enactments. When Bingham made his second proposal for the Fourteenth Amendment, the new language was designed to deprive states of the power to do wrong, not to shift power to the federal government to legislate in traditional areas. ${ }^{280}$ A protection against state government should not shift enactment power to the federal government. But, as Miller pointed out and as reflected in the contemporaneous congressional debates when the Slaughter-House Cases were being decided, a fundamental rights reading of privileges and immunities does that, because fundamental rights include affirmative rights. In short, the fundamental rights interpretation of Justice Bradley also violates the intent of the framers.

The intent of the framers remains a slippery concept with too many plausible accounts competing. As Professor Nelson wrote:

Only one historical conclusion can therefore be drawn: namely, that Congress and the state legislatures never specified whether section one was intended to be simply an equality provision or a provision protecting absolute rights as well. Historical analysis of the framing and ratification of the Fourteenth Amendment cannot, by itself, resolve the dilemma created by the conflicting commitments of those who participated in the process. ${ }^{281}$

Although there are a variety of plausible accounts of the framers' understanding of the privileges or immunities clause, Justice Miller's interpretation of the privileges or immunities clause of the Fourteenth Amendment failed to reflect any of them. The historical record plausibly suggests that the framers intended to forbid inequality in privileges or immunities and to establish limits that would forbid denials of the fundamental rights of citizens including at least some of the Bill of Rights. By limiting the clause to a declaration of the status quo, Justice Miller expressly chose sterility over the potential for expanded federal legislative power. However, the Slaughter-House Cases did not destroy recogni-

279. Id. at 124 (Bradley, J., dissenting).

280. BoGEN, supra note I 68 , at 44-47.

281. Nelson, supra note 255, at I23. See also Timothy M. Bishop, Comments: The Privileges or Immunities Clause of the Fourteenth Amendment: The Original Intent, 79 Nw. U. L. REv. 142 (1984) (arguing that no principled basis exists for choosing among competing versions of intent). 
tion of fundamental rights. Instead, its effect has been to shift analysis from the privileges and immunities clause to the due process clause.

\section{B. The Decision Is Bad Policy}

Although the Slaughter-House Cases did not accurately reflect the history of the privileges or immunities clause, a misreading of history by itself might not be sufficient grounds for overruling the decision. Indeed, if the decision is otherwise beneficial, a reversal for the sake of historical consistency might be foolish indeed. Destroying precedent for the sake of a chimerical original intent is not a good idea. But advocates of reviving the fundamental rights or incorporation substance to the privileges or immunities clause argue that the current tautological interpretation has led to bad results. In short, they contend that the Court's use of the due process clause to accomplish a similar result has undermmed the legitimacy of the Court and cramped its ability to engage in creative interpretations that would further respect individual rights.

\section{Substantive Due Process Is Linguistically Incoherent}

The first objection to the use of the due process clause to accomplish the tasks that the framers hoped would be accomplished by the privileges or immunities clause is that it is linguistically incoherent. ${ }^{283}$ Process refers to procedures, so the clause deals only with lawful procedures. In John Hart Ely's famous phrase: "'substantive due process' is a contradiction in terms - sort of like 'green pastel redness." ${ }^{284}$ Professor Tribe worried that "the doctrinal shakiness of substantive due process may in turn undermine public confidence in the institution of judicial review and in the ability of judges honestly to interpret the dictates of the Constitution." 285

This criticism is disingenuous. "Equal Protection" is a substantive limit on legislatures, and the only textual source for finding the federal government must provide equal protection is the due process clause of the Fifth Amendment. Virtually no one who wants to use the privileges and immunities clause to replace the due process clause of the Fourteenth Amendment on the grounds that "due process" has no substantive content is willing to treat Fifth Amendment due process as purely procedural. ${ }^{286}$ Thus, the linguistic incoherence argument is simply a red herring.

282. Tribe, American Consttumional Law, supra note 9, at 1320-24. Most of the critics of the historical inaccuracy of the decision also argue for a shift either expressly or implicitly.

283. Id. at 1317,1323 .

284. ELY, supra note 98 , at 18 .

285. Tribe, American Consttrutional Law, supra note 9, at 1317.

286. Id. at I3I9 n.37. 
Further, the attack on linguistic incoherence is misdirected. "Substantive due process" is. a shorthand phrase for a concept that is not a contradiction in terms. Process requires procedures for determining the substance of the law as well as the facts. The procedures for finding that the facts should result in deprivation of life, liberty, or property involve the determination of what the law is - that it was passed by Congress and not merely spouted by John Doe. The question, whether an authoritative body passed the law, raises questions about the authority of that body. The deprivation of life, liberty, or property because the facts fit the terms of something which was not law cannot be a deprivation pursuant to lawful procedures. If the law is beyond the power of the legislature, there are no procedures for the deprivation of liberty pursuant to it that would be appropriate.

The linguistic move occurs in the interpretation of the word "liberty" and not "process." What procedures are appropriate for the deprivation of liberty? The law infringing on liberty must be valid constitutionally; otherwise, the application of the law to an individual cannot be appropriate, regardless of the procedure. Procedural due process reads "life, liberty, and property" as the mechanism for exerting the coercive power of the state. In that event, due process is simply the process for determining when the coercive power of the state is exercised on an individual according to existing law. However, if liberty refers to freedom of the individual from state restriction of their behavior, the issue of appropriate procedures shifts from a determination of the applicability of the law to an individual to whether the law is properly enacted and that involves substance as well as legislative process. Linguistically, there is no problem in saying that procedures that are premised on an unconstitutional law violate due process. It is aqua pastelness.

Neither the general public nor the Supreme Court has been particularly troubled by substantive due process as it applies to the incorporation of the First Amendment: How can a law that forbids opposing the government be a law that affords the "appropriate" procedures for depriving someone of speech? We have been living with substantive due process for more than a century with no apparent diminution in respect for the Court. Indeed, the Court has probably gathered more support as an institution in the latter part of the twentieth century than ever before, especially in the area of incorporated rights.

The problem is that due process does not inherently contain any substance to suggest what limits may exist on the legislative power. But neither does it contain substance as to what procedures are due for application in the trial process. We gather them from history and precedent and the specific terms of other constitutional guarantees. The real com- 
plaint is not linguistic, but jurisprudential. Should unenumerated rights be acknowledged, or does that give the Court too much power to frustrate the will of a democracy?

\section{Substantive Due Process Precedents Undermine Respect for the Court}

A second objection raised to the continued use of the due process clause to measure the substantive validity of laws is "the albatross of Lochner." ${ }^{287}$ The saga of that case has been frequently told: how the court substituted "its own judgment, in the absence of any constitutional mandate, for that of the legislature. ${ }^{288}$ It is less frequently noted that Justice Holmes's famed dissent retained a substantive component, conceding that a law would deny "due process" if "it can be said that a rational and fair man necessarily would admit that the statute proposed would infringe fundamental principles as they have been understood by the traditions of our people and our law."289

The problem of Lochner was not linguistic and does not disappear with the change in language from due process to privileges or immunities. Any assertion that an unenumerated right is a "privilege or immunity" of citizenship in the United States will be controversial and raise the argument that the Court is imposing its own views rather than interpreting the document. Once one gets beyond the express provisions of the Bill of Rights, there is no general consensus on the mechanism for ascertaining those rights. The difficulty with Lochner and Dred Scott does not disappear by magic through changing clauses - like a snake shedding its skin, it is still the same old natural law snake. It is hard to imagine an opponent of the decision in Roe v. Wade suddenly saying that the Court would have been acting appropriately if only it had placed its decision on the privileges or immunities clause.

There is a substantial historical argument for the proposition that the Fourteenth Amendment was designed to impose natural law limits on the states. The Court was reluctant to venture into natural law interpretation for the reasons Justice Iredell offered in Calder v. Bull. ${ }^{290}$ Problems of judicial interpretation and the majoritarian difficulty do not

287. Id. at 1319 .

288. Id. at i3i 8; See Michael. J. Phillips, The Lochner Court, Myth and Reality: Substantive Due Process from the i 890 S to The i 930 S 5 (200I).

289. Lochner v. New York, I98 U.S. 45, 76 (1905) (Holmes J., dissenting).

290. 3 U.S. ( 3 Dall.) 386 (1798); "The ideas of natural justice are regulated by no fixed standard: the ablest and the purest men have differed upon the subject; and all that the court could properly say, in such event, would be, that the legislature (possessed of an equal right of opinion) had passed an act which, in the opinion of the judges, was inconsistent with the abstract principles of natural justice." Id. at 398-99 (Iredell, J., concurring). 
vanish depending on the clause used. But, as Justice Holmes seemed to realize, the Fourteenth Amendment gave the Court the power and the obligation to determine those principles, however deferential they should be in applying them. ${ }^{29 \mathrm{r}}$

\section{Privileges and Immunities Has Greater Potential}

A third reason for overturning the Slaughter-House Cases is to inject new life into the search for unenumerated rights. ${ }^{292}$ The due process clause seems to suggest that life, liberty, and property may all be denied if the government does so with due process - but that privileges or immunities have no such conditions. ${ }^{293}$ The move from due process to privileges or immunities could free the court to take another look at natural rights with the argument that the old precedents were created pursuant to different language.

To the extent that a change in textual source unsettles precedents and prods the court to reexamine its prior decisions, the benefits to individual rights are at least questionable. First, the switch could destroy unenumerated rights by restricting privileges to stated constitutional rights as the Slaughter-House revisionists seem to suggest. Second, the call for a reexamination of our jurisprudence and revival of privileges and immunities comes from Justices Rehnquist and Thomas. A court dominated by Thomas, Rehnquist, and Scalia would be likely to contract rather than expand unenumerated rights as their dissents in Planned Parenthood $v$. Casey $^{294}$ suggest. ${ }^{295}$ If any expansion of unenumerated rights occurs, they might well find additional protections for property rights. ${ }^{206}$ Third, if Professor Tribe or Professor Michaelman secured a seat and became intellectually dominant, the expansion of rights and thus the dominance of the Court over the political process would be equally problematic. Although Professor Tribe argues that initially the Court would be guided by the precedents established under due process, there is no assurance that change would follow the same line of progression. ${ }^{297}$ A court far more active in imagining fundamental rights beyond existing traditions is a threat to the political process as grave as one that gives total deference to the legislature.

291. See Lochner, 198 U.S. at 74-76 (Holmes, J., dissenting).

292. See Erwin Chemerinsky, The Supreme Court and the Fourteenth Amendment: The Unfulfilled Promise, 25 Loy. L.A. L. Rev. I 143 , I 147 (1992).

293. See Tribe, American Constitutional LaW, supra note 9, at 1319-20.

294. 505 U.S. 833 (1992).

295. See id at 95I-53. See also Lawrence v. Texas, 123 S. Ct. 2472, 2489-93 (2003) (Scalia, J., dissenting).

296. The concern of these justices for property rights may be seen in their dissents in Brown v. Legal Foundation of Washington, 123 S. Ct. 1406, I422-28 (2003) (Scalia, J., dissenting).

297. Tribe, American Constitutional LaW, supra note 9, at 1328-31. 


\section{Congress Is a Better Institution to Interpret the Clause}

Professor James Fox has argued that the discussion of the meaning of the Fourteenth Amendment and particularly the privileges or immunities clause has suffered from a misplaced focus. Instead of being concerned with the Court's implementation of the historically ambiguous intent of the framers, it is more appropriate, he argues, for the Court to defer to congressional implementation of the Amendment through Section $5^{298}$

Professor Fox appreciates the ambiguity of the history of the clause. Like Professor Curtis, he notes that some of the framers held contradictory goals of federal power to protect life, liberty, and property with continued state sovereignty over basic legal rights. ${ }^{299} \mathrm{He}$ professes his agnosticism on whether the clause should include natural rights beyond enumerated ones, but contends that focus should be on congressional definition of the privileges and immunities clause. He notes how Congress broadly interpreted the Thirteenth Amendment in enacting the Civil Rights Act of 1866 as evidence for the understanding that congressional enforcement power could make vague terms meaningful. ${ }^{300}$

Fox stresses the understanding of natural law fundamental rights as affirmative protections of government. In this respect, he turns to the debates over Civil Rights legislation after the ratification of the Fourteenth Amendment to show how congressmen interpreted the Amendment to empower them to protect individuals from the violence of the Klan and discrimination in places of public accommodations. ${ }^{301}$

Professor Fox urges Slaughter-House be overturned because there was significant historical evidence for a broader view. He admits the historical record "contains sufficient ambiguity that we must confront the possibility that natural or fundamental rights beyond the Bill of Rights could be encompassed by the Clause." ${ }^{302}$ He notes that modern interpretations should look to the interpretations of Congress in the past and he offers a suggestion of a "theory of interpretive enforcement, whereby Congress, in enforcing the broad concept of privileges and immunities, also interprets the Clause by particularizing it. ... Congress may indeed be the most appropriate body, historically and institutionally, to implement the specifics of citizenship privileges and immunities." 303

298. See Fox, supra note 6, at 165 .

299. Id. at 108-09 (citing Curtis, supra note 152).

300. Id. at I 19-22. Fox also applies this understanding to the Anti-Peonage Act. Id. at 1 22-27.

30I. Id. at I $26-48$.

302. Id. at 165 .

303. Id. 
Many critics of the Slaughter-House decision point to the fear of natural rights judicial interpretation as the cue for Miller's rejection of fundamental rights. Tribe suggests that the court's adoption of substantive due process undermines the case.$^{304}$ However, it was primarily the vision of expanded congressional power that drove Miller's decision, and the subsequent case law does nothing to undermine that concern. ${ }^{305}$

\section{Slaughter-House Five: Justice Miller's Vindication}

Justice Miller did not cite the congressional debates, yet he based his interpretation on the intention of the framers and ratifiers of the Fourteenth Amendment. He reached his decision in the context of the same debates over the extent of federal power that Professor Fox uses to argue for an original intent to empower Congress. Miller's opinion rests on the understanding that a "fundamental rights" interpretation of the privileges or immunities clause of the Fourteenth Amendment would necessarily result in federal power to displace state law in traditional areas. That result would have confounded the framers, so in the grand sense he was following the intent of the framers even as he ignored their specific intent. "We are convinced that no such results were intended by the Congress which proposed these amendments, nor by the legislatures of the States which ratified them." ${ }^{306}$

There is substantial support for the proposition that most of the participants in the adoption of the Fourteenth Amendment would have opposed conferring power on Congress to supplant the state as the source of laws on contract, property, and tort. ${ }^{307}$ The real question was whether that result was a necessary consequence of interpreting Fourteenth Amendment privileges or immunities broadly to include the fundamental rights of citizens. A related question is whether other clauses better carry out the framers' intent.

\section{A. The Equal Protection Clause Better Protects Equaltty}

The equality reading of the privileges and immunities clause could probably be cabined to avoid congressional power to enact laws in traditionally local areas such as contract and tort. ${ }^{308}$ However, the narrow

304. Tribe, American Constitutional Law, supra note 9, at 1323.

305. Justice Miller was not frightened of unenumerated rights in every context as shown by his decision in Loan Association v. Topeka, 87 U.S. (20 Wall.) 655, 662-63 (1875) (holding in a diversity of jurisdiction case, applying federal common law, that bonds issued by city to encourage manufacturer to establish there were invalid because not issued for a public purpose).

306. Slaughter-House Cases, 83 U.S. ( 16 Wall.) 36,78 ( 1872 ).

307. See Nelson, supra note 255, at 64-90.

308. A number of congressmen objected to the first proposal of the Fourteenth Amendment, which was in the form of a grant of power to Congress to secure privileges and immunities and equal 
equality interpretation is problematic as a reflection of the framers' intent, ${ }^{309}$ and the framers' concerns for equality are better addressed by the equal protection clause.

Even though some of the framers may have believed that the privileges and immunities clause was concerned with equality, its wording does not focus on that issue. The "equal protection of the laws" directs attention to classifications in legislation, and that clause is the more obvious candidate for assuring non-discrimination. The question was whether the "protection of the laws" was limited to laws for the security of the individual's person or property (e.g., relief for wrongful imprisonment and civil or criminal actions for injury to person or property) or whether it should extend to all laws..$^{310}$ If it extends to all laws, it makes an equality reading of the privileges and immunities clause redundant.

Linguistically there is no difficulty in discerning "protection" in any law where a party seeks equality. The extension serves the purpose that many had for the Fourteenth Amendment with several benefits. First, the clause itself focuses attention on equality and the justifications for distinctions, which was the concern of the framers. Our modern jurisprudence wrestles with understandings of equality based on the paradigm of the illegitimacy of the use of race. This makes more sense than a focus on the content of privileges.

Second, the idea of fundamental rights in connection with privileges and immunities might limit the command of equality inappropriately. The Court now recognizes that privileges and immunities in Article IV apply to every unjustified discrimination against a citizen of another state, not just ones that might be thought fundamental by natural law reasoning, since any unjustified slap at the out-of-stater undermines the common national citizenship that the clause was designed to create. ${ }^{31}$ Similarly, unjustified discrimination against a class of persons in any mat-

protection in the rights of life, liberty and property, on the grounds that it granted a general power to legislate for the protection of life, liberty and property. CoNG. GloBe, 39th Cong., Ist Sess. 1063-64 (1866) (Statement of Rep. Hale). Id. at 1087 (Statement of Rep. Davis); id. at 1095 (Statement of Rep. Hotchkiss); id. at 1082 (Statement of Sen. Stewart). One could argue that the language ultimately adopted also permits uniform national laws to assure states do not deny equal protection as a means of enforcing the prohibition on the denial of equality, but that would be a stretch. Note that Republicans who expressed concern over the scope of federal power voted for the amendment in its current form. Id. at 3042 (Senate vote for amendment includes Stewart); id. at 3I49 (House vote for final version of amendment includes Davis, Hale, and Hotchkiss).

309. See supra Part IV.A.2.

310. Harrison argues that the Equal Protection Clause was limited to the "protection of the laws" as a subset of government activity. The protection is for the personal security of the individual from assault and violence done to person or property-but the definition of property rights would be outside the clause. Harrison, supra note 256, at I433-5I.

3II. See Bogen, supra note I68. 
ter undermines their status as a citizen. Thus, the broad application of equal protection more appropriately serves the function of securing full incorporation of the individual into society as a citizen, because it keeps the focus on the discrimination rather than the "fundamentality" of the subject matter.

Finally, leaving equality to the equal protection clause frees the Court to pay attention to other influences on the Fourteenth Amendment. Fundamental rights, whether enumerated or incorporated, would be lost if the focus of the Fourteenth Amendment was on equality, because due process might easily be limited to the purely procedural realm.

\section{B. The Due Process Clause Better Protects Fundamental Rights}

Unlike state abridgment of fundamental rights, which exists when the state fails to provide adequate laws for the protection of life, liberty, or property, the due process clause is triggered only by state actiontaking of life, liberty, or property. By attaching a substantive meaning to due process, the idea of fundamental rights can be confined to state deprivations. Consequently, as the framers intended, it is a restraint on the state instead of an authorization to the federal government.

Critics complain that substantive due process is an oxymoron. But due process began with the notion of the application of the law to an individual. If government did not act according to the law of the land, it violated Magna Charta. If the law prohibits government from taking a substantive action (a notion specific to the American Constitution), no procedures for taking that action can be process that is "due" under the law. This understanding of due process was reflected in early state case law like Wynehamer, ${ }^{312}$ and in the invalidation of the Missouri Compromise in Dred Scott. ${ }^{313}$ Even Justice Bradley's Slaughter-House Cases list of fundamental rights contained in the Constitution said, "and above all, and including almost all the rest, the right of not being deprived of life, liberty, or property, witlıout due process of law." ${ }^{314}$ Thus, the use of the due process clause as the vehicle for fundamental rights is not inconsistent witl its history. ${ }^{315}$

312. Wynehamer v. People, 13 N.Y. 378, 392-93 (1856).

313. Dred Scott v. Sandford, 60 U.S. (19 How.) 393, 450 (1857).

314 Slaughter-House Cases, 83 U.S. (Wall.) 36 , I 8 ( 1872 ) (Bradley, J., dissenting).

315. See Nelson, supra note 255 , at 57 (stating that the reconstruction committee switched from "equal protection in the rights of life, liberty, and property" into separate clauses for equal protection and due process). That might have been to assure procedural due process. "But a further possibility is that the committee intended to incorporate a concept of substantive due process into the Fourteenth Amendment. That concept had been adumbrated in Scott v. Sandford and in several state cases prior to 1866 , and there is no way of knowing whether the draftsmen of section one meant to incorporate 
Substantive due process also provides a framework for reconciling incorporation issues. ${ }^{316}$ Representative Bingham and Senator Howard believed that the amendment would make the Bill of Rights applicable to the states, and no one in Congress specifically said that they were wrong. But neither proponents nor opponents discussed incorporation during ratification, despite the impact it would have had, which strongly suggests that people did not expect the ainendment to alter state constitutional law. ${ }^{317}$ An equality interpretation of the amendment explains both facts, denying effect to incorporation. The absolute view of rights, however, reconciles the framer's statements with the ratifier's silence by positing that states only considered themselves bound by what was fundamental. States that had different procedures would not consider the constitutional provision on the inatter to relate to a fundamental right, so they could support the amendment without fear that it would change their processes. Inclusion in the Constitution would be evidence that a right was fundamental, but not conclusive. Thus, Binghain and Howard could believe rights were fundainental while states did not feel threatened with change. This view does not resolve whether a particular right should be incorporated, but it suggests that analysis for fundamentality is the appropriate way to proceed. Although that analysis would have been possible under the privileges and immunities clause as well, it would have swept fundamental affirmative rights within the ambit of Congress. Thus, incorporation through the due process clause was the safer way to proceed.

One way in which the shift from privileges and immunities to due process might pose problems for the framers is that fundamental rights become applicable to all persons and not just to citizens. But this should not be particularly troubling: The incorporation of procedural rights fits notions of due process well, and equal protection protects aliens from substantive discriminations unless there are sufficient grounds for distinction. Current doctrine on substantive due process and incorporation permits soine differences in treatment of aliens depending on where they are located and what the grounds for difference may be. The results under due process, therefore, remain consistent with the frainer's imtent.

it." Id. See also Edward S. Corwin, The Doctrine of Due Process of Law Before the Civil War, 24 HaRv.

L. Rev. 366,460 (19II).

316. See David S. Bogen, The Transformation of the Fourteenth Amendment: Reflections from the Admission of Maryland's First Black Lawyers, 44 MD L. REV. 939, 1007 n.225 (1985).

317. See James E. Bond, No Easy Walk to Freedom: Reconstruction and the Ratification of the Fourteenth AmENDMent 221-22 (1997); James E. Bond, The Original Understanding of the Fourteenth Amendment in Illinois, Ohio and Pennsylvania, I8 Akron L. Rev. 435450 (1985); Fairman, Does the Fourteenth Amendment Incorporate the Bill of Rights?, supra note 256, at 32. 


\section{Federalism Remains Good Policy}

This article has suggested that the use of the equal protection clause and the due process clause to assure equality and fundamental rights includimg the Bill of Rights fulfills the historic design of the Fourteenth Amendment more accurately than using the privileges or immunities clause. While the framers may have intended privileges and immunities to have the larger meaning, it would have undercut their concern for federalism to use privileges and immunities as the vessel for that meaning. The other clauses of the Constitution have a sufficient linguistic and historic basis to fulfill that task. Whether they should depends in large measure on one's views of expanded federal power.

Critics may argue that state sovereignty is an outmoded barrier to progressive activity. State's rights were the mantra for racists perpetrating a plethora of evils during segregation, and it may continue to be hurled as a shield against progressive legislation on behalf of individuals. Stopping gun possession near schools ${ }^{318}$ and sexual assault ${ }^{319}$ is nationally desirable, and so is overcoming state sovereign immunity with respect to $\mathrm{age}^{320}$ and disability ${ }^{321}$ laws. Critics may argue that the slew of modern decisions that have put up barriers to federal legislation are just bad, and the Court should expand congressional power by reviving the privileges and immunities clause to create a national form of government.

If the national government otherwise lacked power to deal with national problems, the argument that Miller's decision was bad policy might be convincing. Unless Congress can protect the nation against problems that need national solutions, the benefits of federalism are not worth the price. But just as fundamental rights are adequately protected by the due process and equal protection clauses, the affirmative grants of power to Congress are sufficient to cope with national issues.

The Court still recognizes that Congress has power to enact legislation whenever it is needed to facilitate commerce or prevent it from wreaking harm. ${ }^{322}$ It can regulate goods or activities that cross state

318. United States v. Lopez, 514 U.S. 549, 618-24 (1995) (Breyer, J., dissenting) (invalidating federal statute prohibiting the possession of guns near schools as beyond federal Commerce Clause power).

319. United States v. Morrison, 529 U.S. 598, 634 (2000) (Souter, J., dissenting) (invalidating federal statute giving cause of action to victim of crime of violence motivated by gender as beyond federal Commerce Clause power).

320. Kimel v. Fla. Bd. of Regents, 528 U.S. 62, 93 (2000) (Stevens, J., dissenting) (holding ADEA beyond federal power to enforce the equal protection clause of the Fourteenth Amendment).

32 I. Bd. of Trs. v. Garrett, 531 U.S. 356, 369 (200I) (holding ADA beyond federal power to en. force the Fourteenth Amendment).

322. See Ronald D. Rotunda, The Implications of the New Commerce Clause Jurisprudence: An Evolutionary or Revolutionary Court?, 55 ARK. L. REv. 795, 840-4I (2003). 
lines ${ }^{323}$ and it may also regulate any commercial activity that affects commerce among the states. ${ }^{324}$ The only restriction on the exercise of the commerce power has been with respect to noncommercial intrastate activities where the need for national legislation is highly questionable. Even here, if the states prove inadequate to the task and the noncommercial activity threatens national interests, the federal government retains power in a variety of ways to deal with the problem. ${ }^{325}$

The evil that state's rights rhetoric protected for so long was racial discrimination. But the decision of the Supreme Court in Jones $v$. Mayer $^{326}$ supported federal power to root out private acts of racial discrimination pursuant to Section 2 of the Thirteenth Amendment. ${ }^{327}$ This expansive reading of federal power should be adequate to support the anti-discrimination laws directed at race in housing, education and employment. Justice Miller said that the freedom of the former slaves was the basic thrust of all the Amendments after the civil war:

[T] he one pervading purpose found in them all, lying at the foundation of each, and without which none of them would have been even suggested; we mean the freedom of the slave race, the security and firm establishment of that freedom, and the protection of the newly made freemen and citizens from the oppressions of those who had formerly exercised unlimited dominion over him. ${ }^{38}$

Congress has the power under current interpretations of both the Thirteenth and Fourteenth Amendment to accomplish that purpose, if it can be accomplished through legislation.

323. United States v. Robertson, 514 U.S. 669, 67I (1995) (per curiam).

324. Reno v. Condon, 528 U.S. I4I, I48 (2000) (upholding federal law prohibiting sale of personal information obtained by state motor vehicle administrations).

325. E.g., Congress can use the spending power to induce states to enact desirable laws. See South Dakota v. Dole, 483 U.S. 203 , 21 I-I 2 (I987) (upholding federal law withholding a portion of federal funds unless state raised the legal drinking age for alcohohic beverages to twenty-one). Further, the Court has not foreclosed the use of the Commerce Clause rationale for the situation when a noncommercial act taking place within a state. Even in United States v. Morrison, Chief Justice Rehnquist said "we need not adopt a categorical rule against aggregating the effects of any noneconomic activity in order to decide these cases." 529 U.S. 598, 613 (2000). Although suppression of violence may be a local matter, the Court has not totally foreclosed federal action where that violence truly poses a national problem beyond the capacity of the state to resolve. Indeed, the Court's limits on the cominerce power have not been fully articulated in a principled way and tend to be like Mr. Justice Stewart's famed comınent on obscenity: "I know it when I see it." Jacobellis v. Ohio, 378 U.S. I84, 197 (I964) (Stewart, J. concurring).

326. 392 U.S. 409 (1968).

327. Id at 4I3. (Civil Rights Act of 1866 applies to private discrimination in the sale of property and is a valid exercise of the enforcement power of the Thirteenth Amendment to abolish the badges and incidents of slavery.)

328. Slaughter-House Cases, 83 U.S. ( 16 Wall.) 36,7 I (I872). 
The final concern for states' rights is that individual states may lag behind the federal government in recognizing individual human rights not specifically protected by the Constitution-rights against discrimination because of age, disability, or gender orientation. When denial of such rights impacts interstate commerce, Congress can still regulate it. ${ }^{329}$ Although the recent sovereign immunity doctrine decisions preclude the creation of a private right of action against the state, federal law may still be enforced through Ex Parte Young injunctions and civil and criminal enforcement against the states by the federal government itself..$^{33^{\circ}}$ Further, the Court has shown this term that it is willing to find congressional power to combat behavior that might be rooted in gender or other suspect or quasi-suspect classifications. ${ }^{33^{1}}$

In short, Congress has sufficient power to deal directly or indirectly with every form of national problem. The decisions of the Court, however, demand that Congress demonstrate that the problem is a national one when its scope is not obvious. This demand, and the need to use less direct instruments such as the spending power, force Congress to confront the institutional issue as to which level of government can best deal with the problem. It also makes state sovereignty a practical reality, so that most problems will be understood as state responsibility. There are at least three advantages to maintaining federalism and not interpreting the privileges and immunities clause to confer a general congressional power to legislate on personal security and property rights: it maximizes popular satisfaction, it promotes experimentation, and it provides a model on the international level to reconcile national factions.

The utilitarian argument for federalism is that it maximizes satisfaction. A rule that satisfies the majority in each of the fifty states will be a much larger number than a rule that satisfies the national majority but overrides local state majorities. The wrinkle is the weight to be assigned the desire of persons in one state to have their rule adopted in a neighboring state where there is no significant commercial effect on the first state from such an adoption. Congressional power should be sufficient to enable a national majority to overcome local majorities when that desire is at a high level, but the stumbling blocks that the Court has

329. Thus, the application of the ADA and the ADEA to businesses was not questioned in the decisions that invalidated a private right of action against the states.

330. See, e.g., Alden v. Maine, 527 U.S. 706, 747-48 (1999).

331. Nev. Dep't of Human Res. v. Hibbs, 123 S. Ct. 1972, I977 (2003) (holding that Congress may abrogate state immunity and provide private cause of action for family leave act violation as measure enforcing equal protection clause because law aimed at gender discrimination which is subject to heightened scrutiny.). 
raised to preserve federalism may help preserve local preferences where the national interest is low.

The states have always been famed as the laboratories of experimentation. ${ }^{33^{2}}$ With respect to individual rights, the slow expansion of laws prohibiting discrimination based on gender orientation suggests that states may be even more progressive than the national government, a government whose laws often preempt local attempts to grapple with issues. It may well be that the huge amounts of financing necessary to run for national office create a polarization that does not well reflect a majority. Raising money is easier for the more ideological candidates on each side, and this promotes more strife and less cooperation in the national legislature ${ }^{333}$ Local campaigns are cheaper and need not be as ideologically divisive. That creates the possibility of legislatures more amenable to working together on problems and creating new solutions.

Finally, American federalism has been a model throughout the world for bringing together diverse peoples under a larger governmental structure. ${ }^{334}$ The utility of a national economic policy and a national foreign policy is apparent, but the tug of different ethnic and cultural backgrounds makes this difficult. The breakaway republic of Chechnya in Russia and the fear of separate status for Kurds in Turkey suggest the problems nations may have with significant internal groups with different interests. The lack of autonomy for Tibet gives the Republic of China on Taiwan pause about uniting with the Peoples Republic on the Mainland. If the warning of the anti-federalists coines true, that states cannot maintain their separate sovereignty under a national government, the United States will no longer be the beacon on the hill that gives hope for resolving this kind of international problem. A viable federalism is therefore important, not just for the internal purposes of maximizing popular satisfaction and fostering experimentation, but to demonstrate to a fractious world that dual sovereignty is a viable form of government.

332. See New State Ice Co. v. Liebmann, 285 U.S. 262, 31 I (I932) (Brandeis, J., dissenting) ("It is one of the happy incidents of the federal system that a single courageous State may, if its citizens choose, serve as a laboratory; and try novel social and economic experiments without risk to the rest of the country.")

333. See Mark Tushnet, The New Constitutional. Order i4-i6 (2003).

334. The European Union is one way in which countries have come together in a single governing structure while maintaining separate sovereignty. Canada and Australia are just two of the other nations that have adopted a federal model. In Australia's case, the country carefully considered and rejected the model of a constitutional protection for individual rights, yet retained federalism. 


\section{CONCLUSION}

This Article does not argue that every decision of the Court has been perfect-only that the issues raised on fundamental rights and incorporation are the right ones. The framers did not have answers for modern questions, but left it for the considered judgment of future generations. They did, however, provide a framework to consider whether guarantees of individual rights are fundamental. They sought to assure equality in the laws and to prevent government from acting in ways that trampled on individual rights, but they failed to work through the application of the doctrine. The problems that the courts wrestle with todaybounding the court's discretion with respect to fundamental rights, determining what classifications deny appropriate understandings of equality-are the very problems that the framers left open for the future.

After more than a century, the Slaughter-House Cases have withstood the test of time. Justice Miller's opinion wisely maintained federalism without undercutting the ability of Congress and the court to secure the rights of emancipated slaves through the equal protection clause. It left the door open for the future to discover and apply fundamental rights to restrain state governments through the due process clause, without transferring power to the federal government to supplant the traditional local law of the states. 